\title{
ZRÓŻNICOWANIE POZIOMU WZROSTU GOSPODARCZEGO W WYBRANYCH KRAJACH AFRYKI SUBSAHARYJSKIEJ
}

Przedmiotem opracowania jest analiza wzrostu gospodarczego krajów Afryki Subsaharyjskiej na przestrzeni ostatnich kilkudziesięciu lat, ze szczególnym uwzględnieniem lat 2000-2009.

W regionie Afryki Subsaharyjskiej znajduje się obecnie 47 państw, które dzielą się na trzy zasadnicze grupy: kraje o niskim dochodzie (low income) oraz kraje o średnim niższym (lower-middle income countries) i wyższym dochodzie (upper-middle income countries). Do grupy państw o najniższym dochodzie zaliczamy 29 najbiedniejszych państw Afryki: Benin, Burkina Faso, Burundi, Republikę Środkowoafrykańską, Czad, Komory, Demokratyczną Republikę Konga, Erytreę, Etiopię, Gambię, Ghanę, Gwineę, Gwineę Bissau, Kenię, Liberię, Madagaskar, Malawi, Mali, Mauretanię, Mozambik, Niger, Ruandę, Sierra Leone, Somalię, Tanzanię, Togo, Ugandę, Zambię i Zimbabwe ${ }^{1}$. Wśród państw o niższym średnim dochodzie znajdują się: Angola, Kamerun, Republika Zielonego Przylądka, Republika Konga, Wybrzeże Kości Słoniowej, Lesotho, Nigeria, Wyspy Świętego Tomasza i Książęca, Senegal, Sudan i Suazi, natomiast do grupy wyższej zaliczamy: Botswanę, Gabon, Mauritius, Namibię, Seszele i Republikę Południowej Afryki. W grupie o najwyższych dochodach (high income) znajduje się jedno państwo: Gwinea Równikowa.

$\mathrm{Na}$ początku trzeciego tysiąclecia sytuacja makroekonomiczna regionu afrykańskiego przedstawiała się korzystnie. Po okresie względnej stagnacji w rozwoju, który trwał od uzyskania niepodległości do połowy lat 90., kraje Afryki Subsaharyjskiej ponownie odnotowały wzrost gospodarczy: w latach 2000-2009 średni wzrost PKB wyniósł 4,6\% rocznie, a inflacja osiągnęła niespotykany poziom jednocyfrowy

\footnotetext{
1 Za: World Trade Indicators Country Classification by Region and Income (July 2009 - July 2010), World Bank, www.worldbank.org (25.09.2010).
} 
(już od 1996 r.) $)^{2}$. Wprawdzie sukces krajów afrykańskich nie wydaje się imponujący zarówno w odniesieniu do długości (15 lat), jak i wysokości samego wzrostu, szczególnie w porównaniu z innymi regionami rozwijającymi się świata, jednak wart jest bliższego zbadania.

Na wzrost gospodarczy Afryki Subsaharyjskiej złożyły się liczne czynniki ekonomiczne oraz polityczne. Do najważniejszych czynników ekonomicznych mających wpływ na rozwój gospodarczy państw afrykańskich należą: produkt krajowy brutto, oszczędności oraz handel zagraniczny, jak również pomoc zewnętrzna w formie redukcji zadłużenia i stałego napływu inwestycji zagranicznych. Czynniki polityczne to przede wszystkim rozważna polityka makroekonomiczna wielu państw afrykańskich, obejmująca m.in. szereg reform mających na celu uproszczenie rynku wewnętrznego i wzrost przedsiębiorczości obywateli.

Odrębną grupę stanowią zagrożenia dla wzrostu gospodarczego, jak powszechna korupcja, ograniczająca możliwości wzrostu słaba infrastruktura transportowa i energetyczna, czy wciąż liczne konflikty zbrojne, jednak problem ten podjęty zostanie w kolejnym opracowaniu.

\section{Czynniki ekonomiczne warunkujące wzrost gospodarczy}

\subsection{Produkt krajowy brutto}

Od początku niepodległego bytu kraje Afryki wykazywały stały, choć niewielki wzrost gospodarczy. W większości państw następował on cyklicznie, z przerwami, a okresy wzrostu (lata 60. i 90.) dzielił długi, dwudziestoletni okres stagnacji (1974-1994). Okres ten zapoczątkowała recesja - spowolnienie gospodarki światowej, jakie miało miejsce na początku lat 70 .

Analiza zmian PKB w latach 80. i 90. wskazuje, że średni wzrost PKB w krajach Afryki Subsaharyjskiej w latach 80. wynosił 2,1\% rocznie, a w latach 1990-1995 już tylko 1,17\% (w roku 1992 wzrost był ujemny i wyniósł -1,08\%) ${ }^{3}$. W 1996 r. odnotowany został średni wzrost PKB rzędu 5,05\%, a kolejne lata zaowocowały dalszą poprawą tego wskaźnika: w latach 2003-2008 średni wzrost PKB wyniósł 5,7\%.

\footnotetext{
2 Dane przytaczane w badaniu zostały zaczerpnięte z danych World Development Indicators Banku Światowego (28.09.2010) oraz African Development Indicators Banku Światowego (15.03.2010). Dane dotyczące wielkości inwestycji bezpośrednich pochodzą z zasobów World Investment Report UNCTAD.

3 Dane dotyczące konfliktów zbrojnych pochodzą z UCDP/PRIO Armed Conflict Database.
} 
W latach 1995-2008 średnie tempo wzrostu gospodarczego Afryki Subsaharyjskiej równe było 4,4\% PKB, przewyższając tym samym średnią światową (3,1\%).

W 2000 r. aż 16 państw Afryki Subsaharyjskiej miało roczny wzrost PKB powyżej 5\%. Zdarzały się przypadki znacznie szybszego rozwoju, jak Liberia (25,7\%), Gwinea Równikowa (13,5\%) czy Suazi (10\%). W 2008 r. najszybsze tempo wzrostu miała Angola (14,7\%), za nią Etiopia (11,3\%), Gwinea Równikowa i Ruanda (po 11\%). Ogólnoświatowy kryzys finansowy sprawił, że tempo wzrostu znacznie zmalało, nie było również tak spektakularnych przykładów wzrostu, jak Liberia w 2000 r. Mimo kryzysu, w 2008 r. aż 33 państwa Afryki Czarnej osiągnęły ponad 5\% wzrost PKB - ponad dwukrotnie więcej niż w 2000 r. Zmalała również liczba państw o ujemnym wzroście: z 9 w 2000 r. do 2 w 2008 r.

Te pozytywne tendencje nie przełożyły się na wysokość PKB per capita: w latach 90. dla Afryki Subsaharyjskiej wzrost PKB per capita wynosił średnio -0,6\% rocznie, jedynie w latach 1995-1997 osiągając wartości dodatnie (odpowiednio 1,04\%, 2,31\% i 0,87\%). Porównując wartości bezwzględne, PKB per capita w $2009 \mathrm{r}$. był ponad dwukrotnie wyższy aniżeli w 2000 r. (wzrost z 510 dol. do 1115 dol.). Na wzrost ten nie wpłynęły nawet zmiany cen ropy naftowej po roku 2008.

\section{Rysunek 1. Liczba krajów w poszczególnych przedziałach wzrostu PKB}

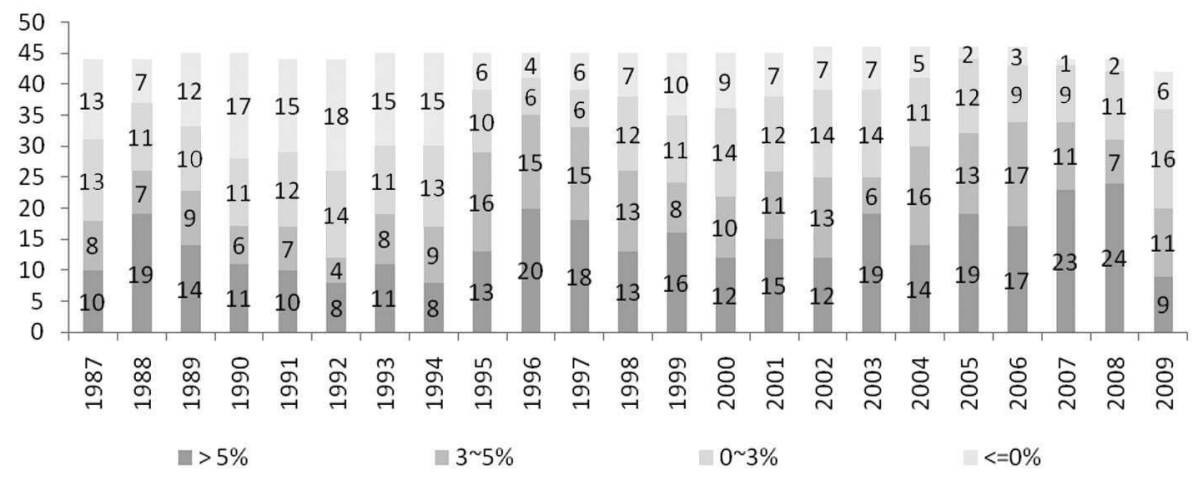

Źródło: opracowanie własne na podstawie World Development Indicators Banku Światowego.

Na początku lat 90. duża grupa krajów Afryki Subsaharyjskiej wykazywała ujemny wzrost: w 1990 r. było to 17 państw, w 1994 r. - 15, a począwszy od 1995 r. liczba ta jest jednocyfrowa, by w roku 2007 ograniczyć się do jednego kraju (Zimbabwe). Od 2000 r. zwiększała się natomiast grupa państw o najwyższym wzroście, aby w 2008 r. osiągnąć rekordową liczbę 24 państw (ponad 50\% regionu). Kryzys światowy zakłócił pozytywne zmiany i spowodował pogorszenie wyników gospodarczych 
państw Afryki, co z kolei przesunęło niektóre państwa do grup o niższym przedziale wzrostu, m.in. zwiększyła się liczba państw afrykańskich z ujemnym wzrostem PKB do 6 (jednak nie wszystkie kraje przedstawiły dane za rok 2009).

Wśród państw Afryki Subsaharyjskiej na uwagę zasługują zwłaszcza Angola, która w latach 1990-1993 miała ujemny wzrost PKB (-0,3\% w 1990 r. i $-24,7 \%$ w 1993 r.), aby od 2002 r. odnotowywać wzrost dwucyfrowy (średnio 14,7\% rocznie). Dwucyfrowy wzrost gospodarczy ma również Etiopia (średnio 11,7\% w latach 2004-2008). Jednak na szczególną uwagę zasługuje Gwinea Równikowa, która rozwija się w przyspieszonym tempie już od 1992 r., odnotowując w 1997 r. wzrost gospodarczy rzędu 71\% w stosunku do roku poprzedniego. Średni wzrost PKB Gwinei Równikowej w latach 1992-2008 wyniósł 23\%.

Rysunek 2. Udział poszczególnych krajów w tworzeniu PKB Afryki Subsaharyjskiej (w \%, 2009)

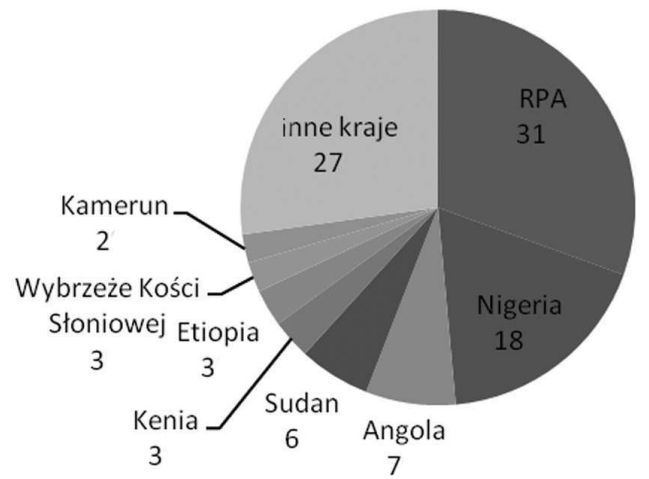

Źródło: opracowanie własne na podstawie World Development Indicators Banku Światowego.

Badanie wykazało znaczne różnice we wzroście $\mathrm{PKB}$ w różnych grupach krajów Afryki Subsaharyjskiej. Największy wzrost odnotowały państwa posiadające bogate zasoby minerałów, a zwłaszcza ropy naftowej, których średni wzrost PKB równy był 6,4\% w latach 2000-2008, podczas gdy kraje nieposiadające bogactw naturalnych odnotowały dwukrotnie mniejszy wzrost rzędu 3,6\%. Państwa posiadające bogactwa naturalne, lecz inne niż ropa naftowa, wykazały w badanym okresie wzrost minimalnie mniejszy od grupy państw eksportujących tenże surowiec (5,6\%). W następstwie kryzysu i spadku cen ropy naftowej wzrost wszystkich państw afrykańskich widocznie osłabł: w 2009 r. wzrost PKB krajów eksportujących surowce energetyczne równy był tylko 1,7\%. Kraje posiadające surowce mineralne, lecz inne niż ropa, wykazywały wzrost równy $2,4 \%$, a kraje ubogie niemal nie zmieniły tempa wzrostu: 3,4\%. 
Surowce naturalne okazały się być determinującym czynnikiem wzrostu dla ponad połowy krajów afrykańskich: spadek cen surowców spowodował natychmiastowe pogorszenie ich sytuacji ekonomicznej.

Najważniejszymi krajami regionu Afryki Subsaharyjskiej są Nigeria i Republika Południowej Afryki. Kraje te tworzą 49\% regionalnego PKB (2009), a mieszka w nich czwarta część populacji regionu ( $200 \mathrm{mln}$ ludzi). Stąd niekorzystne wyniki Nigerii i RPA przekładają się na niekorzystne wyniki całego regionu, zwłaszcza gdy stosowane są miary PKB. Jak wskazuje rysunek 2, największy udział w tworzeniu wartości dodanej Afryki Subsaharyjskiej mają państwa najbogatsze, eksportujące ropę naftową i inne surowce mineralne.

Po roku 2000 nastąpił szybki wzrost PKB per capita - średnia dla Afryki Subsaharyjskiej z lat 2000-2008 równa była 2,4\% i przewyższała średnią światową (1,8\%). W 2008 r. najwyższy poziom PKB per capita odnotowały kraje eksportujące ropę naftową i diamenty (Gwinea Równikowa, Gabon, Botswana, RPA i Angola) oraz afrykańskie potęgi turystyczne: Seszele i Mauritius. Rok 2009 przyniósł spadek obu wskaźników odpowiednio do $-1,2 \%$ i $-3 \%$. W grupie najszybciej rosnących państw ponownie znalazły się kraje bogate w surowce energetyczne, których PKB per capita rosło w tempie 3,8\% rocznie w latach 2000-2008, oraz państwa realizujące odważne reformy wewnętrzne (m.in. Etiopia, Benin, Ghana, Senegal, Tanzania), o podobnym tempie wzrostu. Pozostałe państwa regionu musiały zadowolić się wzrostem rzędu 1,7\%.

Rysunek 3. PKB per capita (w tys. dol., 2008)

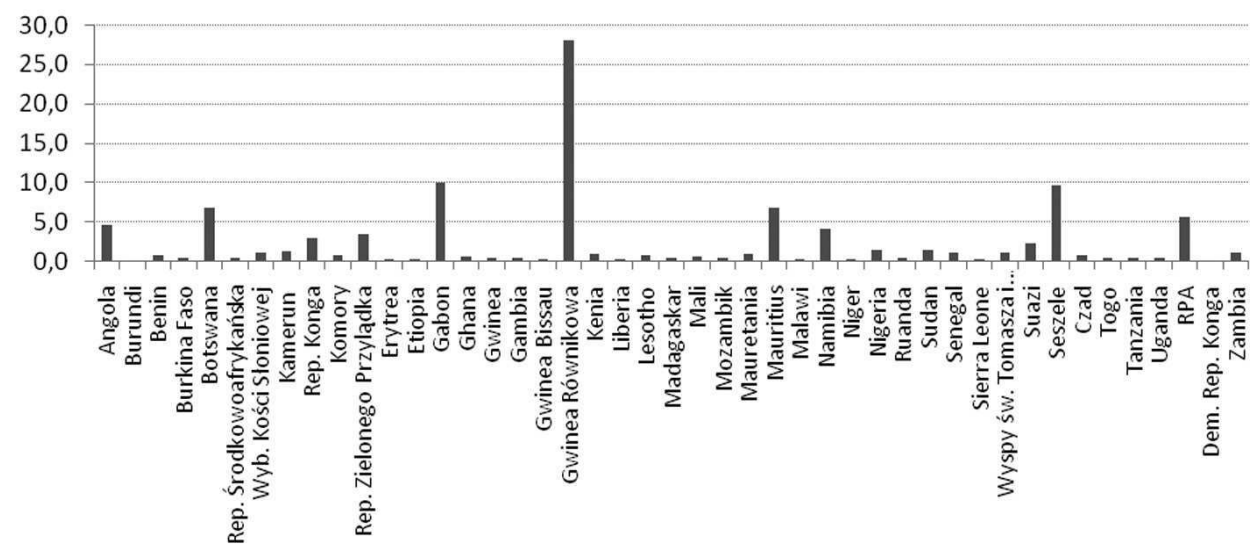

Źródło: opracowanie własne na podstawie World Development Indicators Banku Światowego. 
Istnieje wyraźny związek pomiędzy posiadaniem surowców naturalnych (ropa naftowa lub inne metale i rudy) oraz wielkością PKB per capita. W 2008 r. 26 państw nieposiadających znacznych złóż surowców naturalnych miało średni PKB per capita równy 1360,9 dol. Gdyby jednak wyłączyć z tej grupy Republikę Zielonego Przylądka, Mauritius i Seszele, wówczas PKB per capita maleje do 606 dol. W tym czasie wartość wskaźnika dla krajów posiadających surowce naturalne - inne niż ropa naftowa - równa jest 1993 dol., a dla eksporterów ropy naftowej średnie PKB per capita wynosiła w 2008 r. aż 4264,5 dol.

Wydaje się, że nie ma związku pomiędzy tempem wzrostu gospodarczego a liczbą ludności państw afrykańskich. Państwa o największej liczbie ludności, jak Nigeria (151,3 mln), Etiopia (80,7 mln), Demokratyczna Republika Konga (64,2 mln), Afryka Południowa $(48,7 \mathrm{mln})$, Tanzania $(42,5 \mathrm{mln})$ i Sudan $(41,3 \mathrm{mln})$, miały takie samo tempo wzrostu jak kraje średnie i małe pod względem liczby ludności. Przykładem może być Demokratyczna Republika Konga, w której mieszka około 8\% ludności Afryki Subsaharyjskiej, a której średni wzrost w latach 1961-2008 równy był 0,7\%. Jednak tempo wzrostu gospodarczego krajów najludniejszych znacznie wzrosło $\mathrm{w}$ następstwie reform, jakie zostały w nich przeprowadzone w ostatnich latach.

Rysunek 4. Średni wzrost PKB (w \%, 2000-2008)

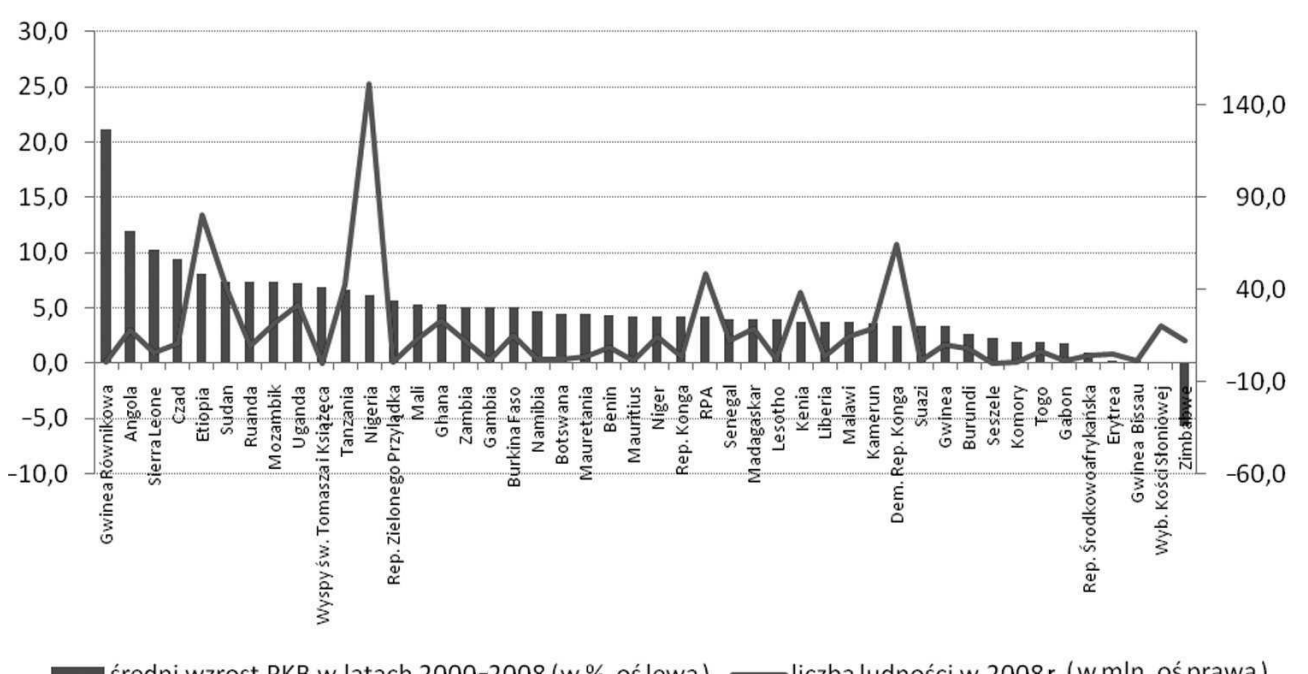

Źródło: opracowanie własne na podstawie World Development Indicators Banku Światowego.

Szczególnym przykładem jest Gwinea Równikowa. Dostępne dane statystyczne pozwalają poddać analizie lata 1986-2009. Kraj ten do początku lat 90. wykazywał 
niewielki wzrost gospodarczy, nawet o wartościach ujemnych. Dopiero rok 1992 przyniósł poprawę wskaźnika: w latach 1992-2008 średni wzrost PKB równy był $17,2 \%$. W 2009 r. tempo wzrostu spadło do $-5,4 \%$.

\subsection{Struktura PKB}

Poprawa sytuacji ekonomicznej państw Afryki Subsaharyjskiej nastąpiła dzięki transformacji gospodarek państw regionu, jaka dokonywała się w ostatnich latach. Mimo zmian Afryka pozostaje jednak regionem w dużym stopniu uzależnionym od rolnictwa, z rozwijającym się dopiero sektorem usługowym i przemysłowym.

Za opóźnienia w rozwoju większości państw afrykańskich odpowiada ograniczona dywersyfikacja struktury gospodarek, przejawiająca się ciągle aktualną dominacją rolnictwa. Ze względu na brak całościowych danych dla większości państw regionu subsaharyjskiego można się posłużyć jedynie nielicznymi znanymi przykładami: w Botswanie, w sektorze rolnym znajduje zatrudnienie niemal $30 \%$ zatrudnionych (2005), w Kamerunie aż 60,6\% (2001), a na Madagaskarze 82\% (2005) - jest to skala niespotykana nigdzie na świecie. Odsetek ten jest znacznie mniejszy w przypadku Republiki Południowej Afryki (8,8\% w 2007 r.) i Mauritiusa (9,1\% w 2007 r.), krajów znacznie bardziej zaawansowanych w rozwoju. Warto nadmienić, że rolnictwo w Afryce wciąż pozostaje niedoinwestowane i uzależnione od warunków pogodowych (susze). Jak wskazują statystyki, jedynie 0,2\% gruntów ornych Afryki Subsaharyjskiej została nawodniona (2007).

W państwach Afryki Subsaharyjskiej w 2008 r. średnio 14,62\% PKB pochodziło $z$ rolnictwa. Po wykluczeniu danych dotyczących RPA oraz Nigerii udział rolnictwa w PKB wzrasta do $20 \%$. Wciąż jednak istnieją ogromne różnice pomiędzy poszczególnymi krajami. Jak pokazuje rysunek 5, w państwach o największym sektorze rolnym (40-50\% wartości dodanej) dochód per capita pozostawał niewielki. Do grupy tej należą m.in. Gwinea Bissau (51\%), Republika Środkowoafrykańska (50\%), Komory (46\%), Sierra Leone (41\%) czy Etiopia (40\%). Po przeciwnej stronie znajdują się kraje, w których sektor rolny jest niewielki (w Botswanie równy tylko 1,6\%), a które mają jedne z największych dochodów per capita w regionie. Wyróżnia się zwłaszcza Gwinea Równikowa o dochodzie per capita równym 28 tys. dol. przy $2 \%$ udziale rolnictwa w PKB. Ponadto Gabon (9,9 tys. dol. i 5\% udział rolnictwa w PKB), Seszele (9,6 tys. dol. i 2,3\% udział rolnictwa w PKB) czy Mauritius (6,8 tys. dol. oraz $4 \%$ udział rolnictwa w $\mathrm{PKB})$. 
Rysunek 5. Udział rolnictwa w PKB (w \%, 2008)

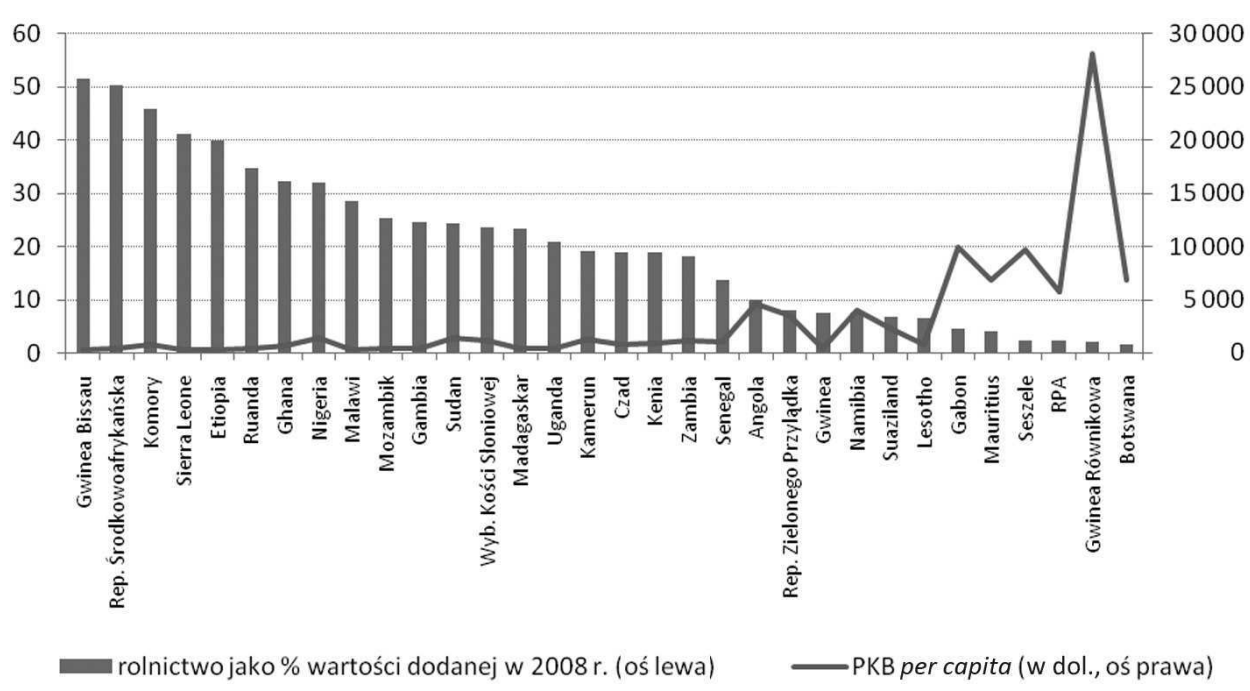

Źródło: opracowanie własne na podstawie World Development Indicators Banku Światowego.

Udział pozostałych sektorów gospodarki w tworzeniu PKB wciąż rośnie, jednak znacznie wolniej niż w innych krajach rozwijających się świata. Średni udział przemysłu w tworzeniu PKB już na początku lat 80. przekroczył 30\%, a w 2008 r. osiągnął $37 \%$. Wśród państw regionu pozytywnie wyróżniają się kraje bogate w surowce mineralne, głównie ropę naftową i gaz ziemny, ale także mangan i uran (Gabon) czy diamenty (Angola), których PKB w przeważającej większości pochodzi z produkcji przemysłowej. Jak wskazuje rysunek 6, istnieje wyraźny związek pomiędzy udziałem przemysłu w tworzeniu wartości dodanej a wielkością PKB per capita. Kraje o najwyższym udziale przemysłu w strukturze PKB mają także wysoki PKB per capita. Ponownie niezwykłym przypadkiem jest Gwinea Równikowa, która 95\% wartości dodanej zawdzięcza surowcom energetycznym. Gros państw afrykańskich (19) mieści się w przedziale $20-40 \%$.

Udział usług w tworzeniu wartości dodanej w przeważającej większości państw Afryki Subsaharyjskiej (28) przekracza 20\%. Sektor usługowy najważniejszy jest na Seszelach (75\%) i w Namibii (65\%), natomiast najmniejszy udział ma w Gwinei Równikowej (2,3\%) oraz Angoli (3,7\%) - krajach zdominowanych przez sektor wydobywczy surowców energetycznych. Średni udział usług w tworzeniu wartości dodanej w regionie subsaharyjskim już od początku lat 60 . kształtował się na poziomie 35-38\% PKB. Tendencję wzrostową możemy zaobserwować od połowy lat 80 . do około 2004 r., po czym nastąpił nieznaczny spadek wartości wskaźnika do poziomu 
$\mathrm{z}$ lat 60. Brak związku pomiędzy udziałem usług w tworzeniu wartości dodanej a wielkością $\mathrm{PKB}$ per capita.

Rysunek 6. Udział przemysłu w PKB (w \%, 2008)

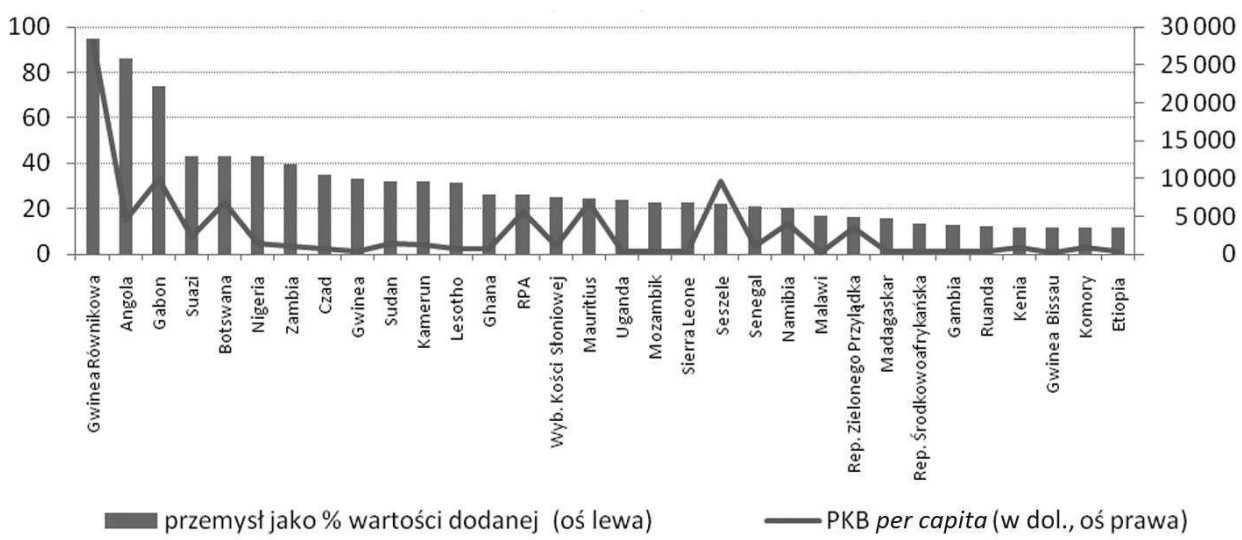

Źródło: opracowanie własne na podstawie World Development Indicators Banku Światowego.

Rysunek 7. Udział usług w PKB (w \%, 2008)

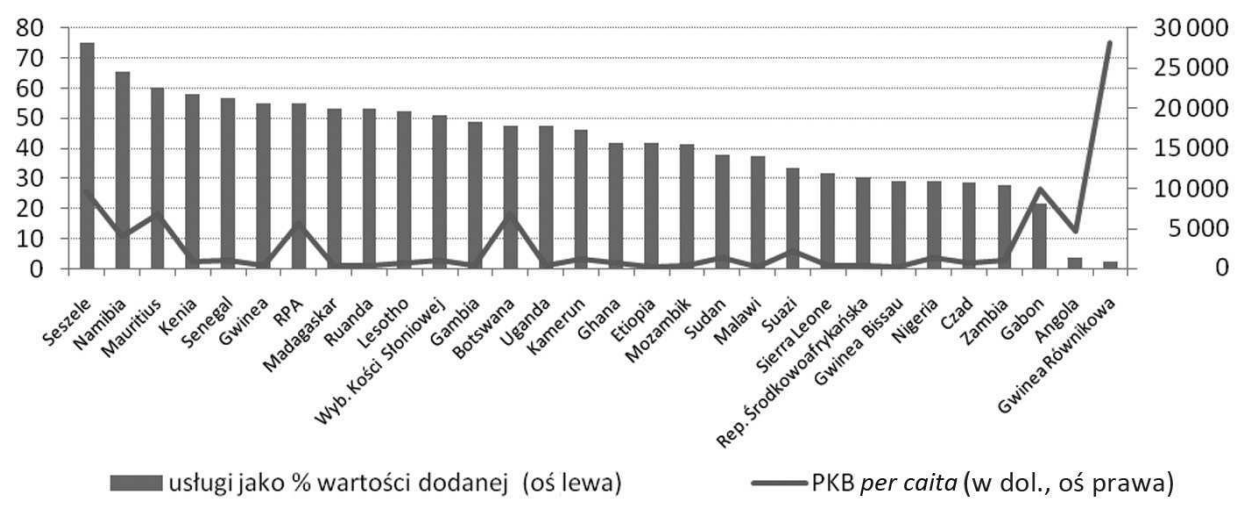

Źródło: opracowanie własne na podstawie World Development Indicators Banku Światowego.

Struktura PKB Afryki Subsaharyjskiej nie determinuje wzrostu gospodarczego, ale też go nie przekreśla. Obok państw o wciąż silnym sektorze rolnym (Gwinea Bissau, Republika Środkowoafrykańska, Komory, Sierra Leone, Etiopia) funkcjonują kraje, których PKB zdominowany jest przez przemysł (Gwinea Równikowa, Angola, Gabon) lub usługi (Seszele, Mauritius, Namibia, Kenia, Senegal). Na pewno 
państwa Afryki powinny dążyć do ograniczenia roli sektora rolnego w tworzeniu wzrostu gospodarczego.

\subsection{Oszczędności}

Do przyspieszenia wzrostu gospodarczego przyczynić się może wykorzystanie oszczędności, które uważane są za bezpieczny, tani i trwały sposób inwestycji. Jednak Afryka Subsaharyjska posiada najniższy poziom oszczędności na świecie.

Rysunek 8. Udział oszczędności w wartości dodanej (w \%, 1960-2009)
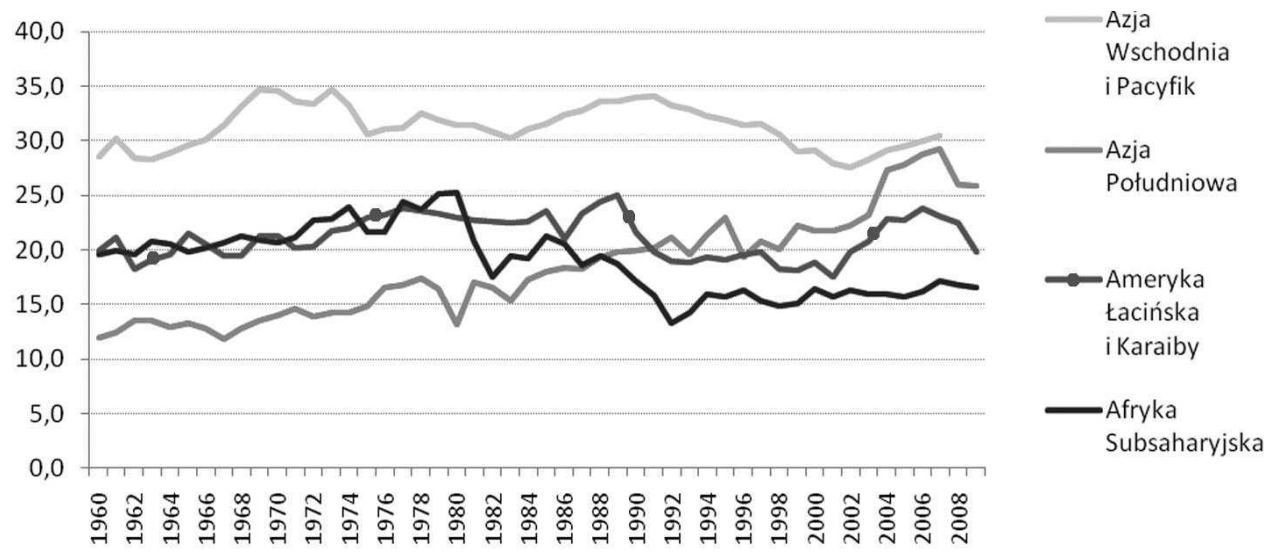

Źródło: opracowanie własne na podstawie World Development Indicators Banku Światowego.

W 2009 r. oszczędności stanowiły w Afryce Subsaharyjskiej jedynie 16,5\% PKB, podczas gdy w innych regionach rozwijających się było to odpowiednio: 30,4\% PKB (Azja Wschodnia i Pacyfik, 2007), 25,9\% PKB (Azja Południowa) oraz 19,8\% PKB (Ameryka Łacińska i Karaiby). Jak wynika z rysunku 8, kraje Afryki Subsaharyjskiej dysponują niewielkimi środkami, które od początku lat 70. ulegają dalszemu spadkowi. Za ten stan odpowiadają m.in. niskie przychody per capita i słabo rozwinięty rynek finansowy Afryki: brak zwyczaju oszczędzania w bankach i zbyt niskie oprocentowanie, zniechęcające do gromadzenia oszczędności. Dodatkową przeszkodę stanowi fakt, iż część oszczędności afrykańskich posiada formę ograniczającą możliwość inwestycji - zwłaszcza w rolnictwie, gdzie mieszkańcy Afryki lokują oszczędności w zwierzęta hodowlane, maszyny i urządzenia czy meliorację pól.

Gros oszczędności nagromadzonych jest w krajach bogatych w surowce naturalne, które znacznie zawyżają średnią. W 2009 r. eksporterzy ropy naftowej zaoszczędzili 112,1 mld dol., co stanowiło 48\% oszczędności regionu (234 mld dol.). Region 
Afryki Subsaharyjskiej w latach 60., 70. i 80. odnotowywał średnie oszczędności na poziomie $20,9 \%$ PKB. Począwszy od 1990 r., średnie oszczędności regionu zmalały do 15,8\% PKB. Niektóre kraje odnotowują ujemny stopień oszczędności. Zaliczamy do nich m.in. Liberię, która w latach 2000-2009 miała oszczędności rzędu -38,4\% PKB, za nią Lesotho (-26,3\% PKB), a także Komory (-8,4\% PKB) i Republika Zielonego Przylądka (-2,6\% PKB). Na przestrzeni ostatnich dziesięciu lat przeważająca większość państw afrykańskich odnotowywała oszczędności dwucyfrowe, a średnia dla Afryki Subsaharyjskiej w latach 2000-2009 równa była 16,2\% PKB. W szczególnie dobrej sytuacji jest Gwinea Równikowa (oszczędności rzędu 79,5\% PKB), a także Gabon (53,2\% PKB), Botswana (36,5\% PKB) i Angola (32\% PKB). W przypadku Botswany już od połowy lat 80. oszczędności przekroczyły na stałe poziom $36 \%$, aby w latach 2000-2008 średnio wynieść 50\% PKB. W najgorszej sytuacji jest Liberia, która od 2001 r. tylko dwukrotnie (w latach 2004-2005) miała dodatni poziom oszczędności, a w latach 2006-2008 nastąpił ich gwałtowny spadek: w 2006r. do $-34,6 \%$ PKB, w 2007 r. do $-142,5 \%$ i w 2008 r. do $121,5 \%$ PKB.

\section{Rola zagranicznych środków pomocowych w rozwoju}

W gospodarce afrykańskiej dużą rolę odgrywają zagraniczne przekazy finansowe w postaci bezpośrednich inwestycji zagranicznych (Foreign Direct Investment, FDI), pomocy na rzecz rozwoju (Official Development Aid, ODA), a także środków przesyłanych rodzinom przez pracujących za granicą obywateli.

Bezpośrednie inwestycje zagraniczne mają duże możliwości oddziaływania na wzrost gospodarczy krajów słabo rozwiniętych. Napływ inwestycji zwiększa krajowe oszczędności, a poprzez ograniczenie kosztów kapitałowych zwiększa również wzrost. Korzyści pośrednie to wzrost produktywności dzięki transferom know-how i nowych technologii, a także wzrost kwalifikacji siły roboczej i konkurencyjności przedsiębiorstw krajowych zarówno na rynku wewnętrznym, jak i rynkach zagranicznych. Niezmiernie ważne są tzw. efekty rozlania (spillover) inwestycji zagranicznych, polegające na przenoszeniu się korzyści na inne sektory gospodarki. Mają one jednak zmienną wagę, w zależności od rodzaju inwestycji (np. inwestycje w sektor wydobywczy mają ograniczony wpływ na produkcję innych gałęzi gospodarki czy na zatrudnienie) $)^{4}$.

\footnotetext{
4 E. Dabla-Norris, J. Honda, A. Lahreche, G. Verdier, FDI Flows to Low-Income Countries: Global Drivers and Growth Implications, „IMF Working Paper” June 2010, Nr 10/132, s. 15.
} 
Skuteczne wykorzystanie napływających do kraju środków finansowych warunkuje wiele czynników. Należą do nich m.in. rozwinięty sektor finansowy, który sprawnie rozlokuje środki zagraniczne, a także będzie w stanie udostępnić potrzebne środki dodatkowe. Duże znaczenie ma również stopień rozwoju infrastruktury, która niejednokrotnie warunkuje nie tylko efektywne wykorzystanie pomocy, ale wręcz jej pozyskanie. Szczególnie ważna jest możliwość przyłączenia do sieci energetycznej. Istotnym elementem jest także rozwój instytucjonalny kraju, umożliwiający operowanie przedsiębiorstwa zagranicznego na rynku wewnętrznym i jego współpracę z przedsiębiorstwami lokalnymi. Napływ inwestycji zależy także od posiadania odpowiednio wykwalifikowanej siły roboczej oraz od polityki makroekonomicznej rządu, m.in. w zakresie inflacji. Na napływ inwestycji zwykle korzystnie wpływa otwarcie gospodarki krajowej na handel zagraniczny i orientacja proeksportowa. Siła oddziaływania środków finansowych z zagranicy zależy więc nie tylko od ich wielkości. Gros wysiłku leży po stronie krajów przyjmujących, w których interesie leży ich jak najlepsze wykorzystanie.

\subsection{Bezpośrednie inwestycje zagraniczne}

W ciągu ostatnich 10 lat (2000-2009) wartość inwestycji zagranicznych w Czarnej Afryce niemal przez cały okres wykazywała tendencje wzrostowe, osiągając w 2008 r. rekordową wartość 50,68 mld dol. ${ }^{5}$ Dopiero w 2009 r. w całym regionie odnotowany został spadek rzędu $14,5 \%$ wolumenu inwestycji w stosunku do roku poprzedniego (z 50,68 mld dol. do 43,31 mld dol.). Wciąż jednak region przyjął więcej FDI aniżeli w latach poprzednich: w $2007 \mathrm{r}$. jedynie 1,94\% inwestycji światowych trafiło do Afryki Subsaharyjskiej, podczas gdy w 2009r. wskaźnik ten wzrósł do 3,89\%. Rósł także udział Afryki Subsaharyjskiej w grupie krajów rozwijających się: z 7,2\% w 2007 r. do 9,05\% w 2009 r., mimo ogólnego spadku wolumenu inwestycji (FDI światowe zmniejszyły się z $630 \mathrm{mld}$ dol. do 478,3 mld dol. w latach 2008-2009). W 2009 r. największy udział w światowych inwestycjach bezpośrednich miała Azja, do której trafiło 63\% inwestycji, za nią Ameryka (24\%). Oceania przejęła śladową część środków (0,4\%).

5 Dane liczbowe dotyczące bezpośrednich inwestycji zagranicznych zostały zaczerpnięte z: Major FDI Indicators (WIR 2010), UNCTAD, www.unctad.org (25.09.2010) lub z zasobów World Development Indicators Banku Światowego (28.09.2010) oraz African Development Indicators Banku Światowego (15.03.2010). 
Rysunek 9. Napływ FDI do regionów rozwijających się (w mld dol., 1980-2009)

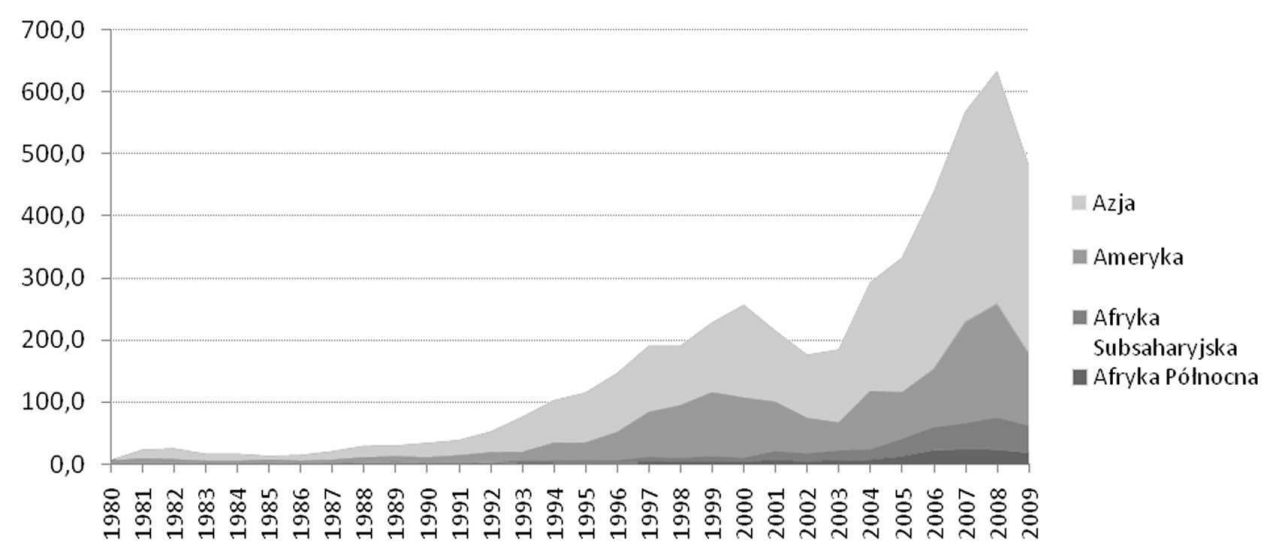

Źródło: opracowanie własne na podstawie Major FDI Indicators, World Investment Report 2010.

Rozkład wolumenu inwestycji w poszczególnych państwach kontynentu wykazuje znaczne zróżnicowanie. Zdecydowanie największym odbiorcą inwestycji była Angola, w której ulokowanych zostało łącznie 29,7 mld dol., co stanowi aż 31,7\% całości inwestycji w Czarnej Afryce w latach 2008-2009. Wielkość inwestycji przyjętych przez Angolę jest niewiele mniejsza niż suma inwestycji pozostałych państw (poza RPA, Nigerią i Sudanem). Na drugim miejscu znajduje się RPA (14,7 mld dol.), potem Nigeria (12,7 mld dol.) i Sudan (5,6 mld dol.). Tak duży napływ środków zagranicznych wiązał się ze wzrostem wydobycia i rosnącymi cenami surowców energetycznych. Pozostałe państwa regionu (zdecydowana większość) musiały zadowolić się inwestycjami o wartości do $1 \mathrm{mld}$ dol. (41 państw). Minimalne inwestycje otrzymały Komory (17 mln dol.), Gwinea Bissau (20 mln dol.), Burundi ( $24 \mathrm{mln}$ dol.), Wyspy Świętego Tomasza i Książęca (68 mln dol.), Togo ( $74 \mathrm{mln}$ dol.) i Sierra Leone ( $86 \mathrm{mln}$ dol.). Tylko dwa kraje odnotowały inwestycje ujemne: w 2008 r. była to Gwinea Równikowa (-794 mln dol.), a rok później Mauretania (-38,3 mln dol.). W 2009 r. Gwinea Równikowa poprawiła swoje wyniki, otrzymawszy 1,6 mld dol., stanowiące $3,8 \%$ całości inwestycji w 2009 r. 
Rysunek 10. Inwestycje zagraniczne w Afryce Subsaharyjskiej (w mln dol., 2008-2009)

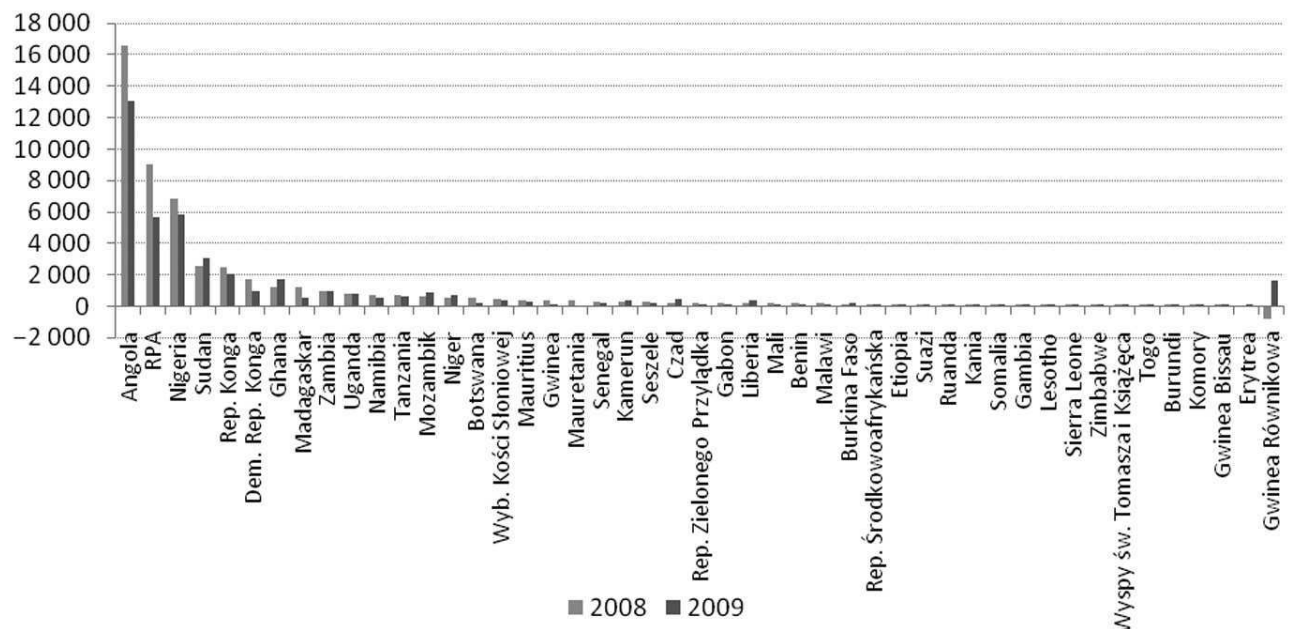

Źródło: opracowanie własne na podstawie World Development Indicators Banku Światowego.

Spośród regionów Czarnej Afryki największe inwestycje zagraniczne lokowane były w Afryce Południowej (przede wszystkim w RPA), która na przestrzeni ostatnich kilkunastu lat znacząco zwiększyła wydobycie ropy naftowej. W ostatnich latach także Afryka Zachodnia i Wschodnia przyjmowały wiele inwestycji związanych z przemysłem wydobywczym, jednak od kilku lat napływ środków do regionu ulega zmniejszeniu. W Afryce Zachodniej inwestorzy współpracowali przede wszystkim z Nigerią (5,85 mld dol.), Ghaną (1,68 mld dol.) i Nigrem ( $0,73 \mathrm{mld}$ dol.). Wśród państw Afryki Wschodniej prym wiodły Zambia (0,95 mld dol.), Mozambik (0,88 mld dol.) oraz Uganda ( $0,8 \mathrm{mld}$ dol.). Afryka Środkowa to nade wszystko inwestycje w Angoli (13,1 mld dol.), Demokratycznej Republice Konga (2,08 mld dol.) i Gwinei Równikowej (1,63 mld dol.). Wciąż duże zainteresowanie inwestorów Gwineą Równikową oraz Angolą sprawiło, że jest to jedyny region odnotowujący ciągły wzrost wolumenu inwestycji.

Wraz ze wzrostem wartości bezwzględnych rósł udział bezpośrednich inwestycji zagranicznych w PKB Afryki. Podczas gdy w latach 1974-1994 średni poziom FDI dla grupy krajów Afryki Subsaharyjskiej wynosił tylko 0,9\% PKB, w latach 1995-2007 osiągnął poziom 4,4\% PKB. Wzrost udziału inwestycji w wartości dodanej nastąpił we wszystkich krajach, a średni wskaźnik w latach 2000-2007 był prawie jednakowy: w krajach posiadających surowce energetyczne średni udział inwestycji zagranicznych w PKB równy był 3,9\%, w państwach posiadających inne bogactwa mineralne wskaźnik ten wyniósł $3,8 \%$, podczas gdy w pozostałej grupie państw udział inwestycji wyniósł aż 4,4\% PKB. 


\section{Inwestorzy}

Inwestycje zagraniczne w Afryce w przeważającej większości pochodzą z państw rozwiniętych (72\% napływu FDI w latach 2000-2008). Jednak wskaźnik ten wykazuje tendencje spadkowe: w porównaniu z okresem 1995-1999 zmalał o 7 pkt. proc. Mimo to w $2008 \mathrm{r}$. kraje rozwinięte posiadały ponad $91 \%$ zainwestowanego kapitału. Spośród regionów rozwijających się znaczącym partnerem są państwa azjatyckie, dostarczające ponad 15\% inwestycji zagranicznych w latach 2000-2008. Wśród nich najbardziej aktywne są rozwijające się szybko Chiny. W ostatnich latach zmniejszeniu uległy inwestycje z regionu Ameryki Łacińskiej i Karaibów (z 5,5\% w latach 1995-1999 do 0,7\% w okresie 2000-2008) oraz Europy Południowo-Wschodniej i WNP.

Tabela 1. Rozkład inwestycji zagranicznych w Afryce

\begin{tabular}{|l|c|c|}
\hline \multirow{2}{*}{\multicolumn{1}{c|}{ Region pochodzenia środków }} & \multicolumn{2}{|c|}{ Udział w inwestycjach światowych (napływ w \%) } \\
\cline { 2 - 3 } & $\mathbf{1 9 9 5 - 1 9 9 9}$ & $\mathbf{2 0 0 0 - 2 0 0 8}$ \\
\hline Świat & 100,0 & 100,0 \\
\hline Kraje rozwinięte & 79,0 & 72,1 \\
\hline Kraje rozwijające się & 17,7 & 20,8 \\
\hline Afryka & 5,1 & 4,9 \\
\hline Ameryka Łacińska i Karaiby & 5,5 & 0,7 \\
\hline Azja & 6,7 & 15,2 \\
\hline Europa Południowo-Wschodnia i WNP & 0,3 & 0,0 \\
\hline
\end{tabular}

Źródło: World Investment Report 2010: Investing in a Low-Carbon Economy, United Nations, New York and Geneva 2010, s. 34 .

Inwestycje wewnętrzne w regionie w 2009 r. pozostały niewielkie, na poziomie około 5\% całości inwestycji, jakie napłynęły do Afryki. Mimo to udział inwestycji intraregionalnych w całkowitym zasobie FDI w poszczególnych krajach afrykańskich jest istotny w takich krajach, jak: Tanzania (43\% w 2005 r.), Botswana (32\% w 2007 r.), Madagaskar (21\% w 2005 r.), Malawi (27\% w 2004 r.) czy Uganda (18\% w 2003 r.) $)^{6}$.

Najważniejszym inwestorem spośród krajów rozwijających się jest RPA, skąd pochodzi ponad 50\% inwestycji Botswany, Demokratycznej Republiki Konga, Lesotho, Malawi i Suazi ${ }^{7}$. W 2008 r. udział krajów afrykańskich w wolumenie inwestycji zagranicznych RPA wzrósł do 22\%, z 5\% jeszcze w 2000 r., osiągając kwotę

6 World Investment Report 2010: Investing in a Low-Carbon Economy, United Nations, New York and Geneva 2010, s. 36.

7 Foreign direct investment and financing for development: trends and selected issues, UNCTAD, TD/B/COM.2/80, 7 December 2007, s. 5. 
niemal 11 mld dol. Większość inwestycji południowoafrykańskich koncentrowała się w sektorze telekomunikacji, infrastruktury, wydobywczym i energetycznym ${ }^{8}$.

Państwa rozwijające się, w przeciwieństwie do krajów rozwiniętych, nie zmieniły swojej strategii inwestycyjnej w obliczu kryzysu, a ich inwestycje w Afryce Subsaharyjskiej wciąż wykazują tendencję rosnącą. Poza RPA największym inwestorem z krajów rozwijających się były Chiny, które w latach 2006-2008 ulokowały w Afryce 2,5 mld dol., za nimi Malezja (6,1 mld dol.), Indie (0,3 mld USD), a także Tajwan, Korea Płd., Chile, Turcja i Brazylia.

Rysunek 11. Kraje rozwijające się inwestujące w Afryce (w mln dol., 2006-2008)

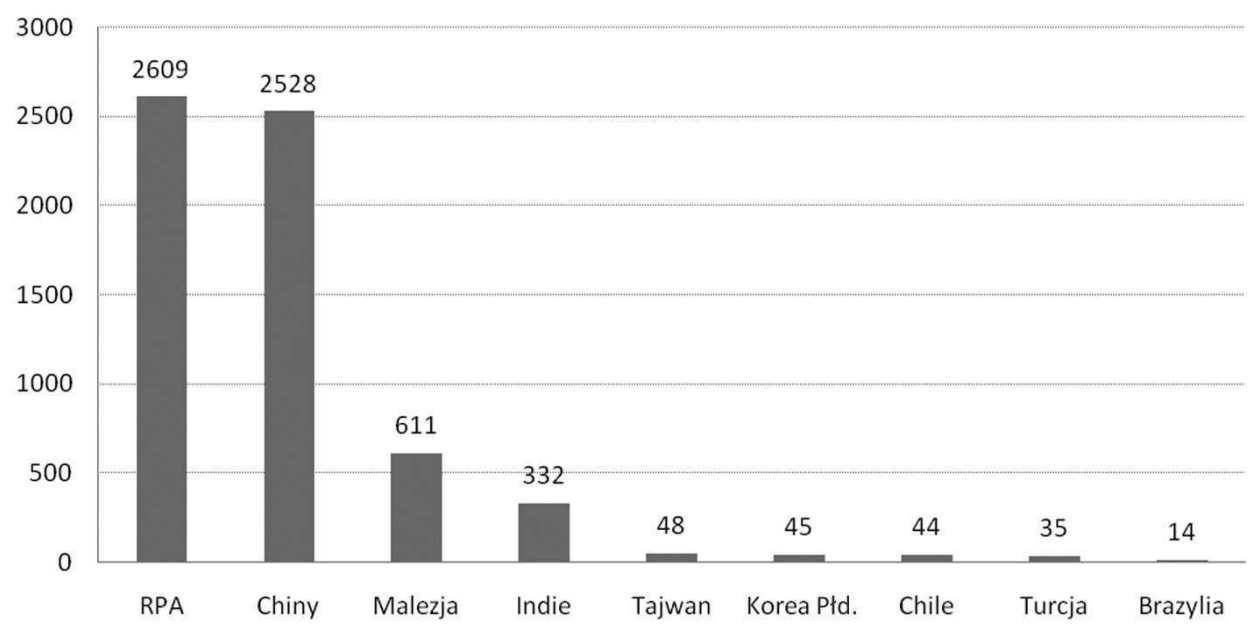

Źródło: World Investment Report 2010..., op.cit., s. 35.

$\mathrm{Za}$ inwestycjami stoi wysokie zapotrzebowanie gospodarek azjatyckich na surowce mineralne, zwłaszcza energetyczne. Kraje azjatyckie największych inwestycji pod względem wartości dokonały w sektorze wydobywczym, liczne były również kontrakty na rozbudowę i modernizację infrastruktury, jak również na produkcję przemysłową. Warto podkreślić, że inwestycje chińskie dokonywane były zwykle przez przedsiębiorstwa w całości bądź w części należące do państwa, czego przykładem jest m.in. chińska korporacja China National Offshore Oil Corporation (CNOOC).

Władze w Pekinie wybrały państwa afrykańskie spośród swoich najważniejszych partnerów gospodarczych, w których mają żywotne interesy i z którymi utrzymują

8 World Investment Report 2010..., op.cit., s. 36. 
bliskie relacje polityczne. Pierwsza SSE powstała w Zambii, w regionie Chambishi, skąd ChRL otrzymuje miedź, diamenty, kobalt i uran. W zamian za umieszczenie kolejnych inwestycji rząd Zambii zadeklarował poparcie idei jednych Chin. Łączna inwestycja ChRL obejmuje m.in. pożyczkę w wysokości $800 \mathrm{mln}$ dol., ulgi celne i podatkowe, a przede wszystkim hutę miedzi o wartości $250 \mathrm{mln}$ dol. W strefie tej zatrudnienie znaleźć ma 60 tys. Zambijczyków i Chińczyków. Druga strefa powstaje na Mauritiusie, atrakcyjnym ze względu na liczną diasporę chińską, korzystne usytuowanie na Oceanie Indyjskim, ale też rozwinięte centrum finansowe i atrakcyjne prawo inwestycyjne. Mauritius, należący do regionalnych organizacji międzynarodowych (Wspólnego Rynku Afryki Wschodniej i Południowej, COMESA oraz Południowoafrykańskiej Wspólnoty Rozwoju, SADC) ma także preferencyjny dostęp do rynków wewnętrznych państw afrykańskich. W SSE powstać mają przede wszystkim zakłady przemysłowe produkujące tekstylia, sprzęt elektryczny i niewielkie urządzenia przemysłowe. ChRL przewiduje, że zatrudnienie znajdzie tam około 13 tys. osób. Kolejna SSE powstać ma w Tanzanii, w Dar es Salaam, które ma służyć jako port przeładunkowy dla surowców wydobywanych w Zambii i Afryce Wschodniej. W 2007 r. powstała SSE w Nigerii, ze względu na jej zasoby ropy naftowej, duży rynek wewnętrzny i łatwy dostęp do rynków Afryki Zachodniej i Europy ${ }^{9}$.

Indie największym zainteresowaniem darzą Mauritius ze względu na jego centrum usług finansowych oraz korzystne rozwiązania podatkowe. Poza Mauritiusem Indie inwestują m.in. w Senegalu, Wybrzeżu Kości Słoniowej i Sudanie. Przykładem jest ekspansja indyjskiego operatora sieci komórkowej Bharti Airtel, który dzięki zakupowi operatorów komórkowych w 15 krajach afrykańskich od Zain Group (transakcji wartej 10,7 mld dol.) oraz Telecom Seychelles Ltd., wartej $62 \mathrm{mln}$ dol., stał się jednym z pięciu największych operatorów sieci komórkowej na świecie i jest obecny w 16 krajach afrykańskich ${ }^{10}$.

Afryką Subsaharyjską zainteresowane są także kraje Bliskiego Wschodu, w tym członkowie Rady Współpracy Zatoki Perskiej. Inwestycje krajów arabskich koncentrują się w sektorze rolnym, a ich najważniejszymi partnerami są Sudan, Tanzania i Etiopia.

Inwestorzy z krajów rozwijających się częściej preferują inwestycje typu greenfield, dzięki czemu kraj goszczący szybciej odczuwa pozytywne skutki napływu środków finansowych. Inwestycje typu greenfield najczęściej dotyczą sektora usługowego, szczególnie usług finansowych i biznesowych. W krajach rozwijających się

9 M.J. Davies, Special Economic Zones: China's Developmental Model Comes to Africa, w: China into Africa. Trade, Aid, and Influence, red. R.I. Rotberg, Brookings Institution Press, Washington, D.C. 2008, s. $143-150$.

10 www.bharti.com (16.09.2010). 
bezpośrednie inwestycje zagraniczne lokowane są $\mathrm{z}$ reguły w sektorze wydobywczym. Dopiero w drugim rzędzie inwestorzy zagraniczni zaczynają interesować się produkcją i usługami. Ostatnie lata przyniosły rosnące zainteresowanie sektorem telekomunikacyjnym.

FDI z krajów rozwijających się pochodzą głównie z przedsiębiorstw państwowych, znacznie bardziej odpornych na kryzys niż przedsiębiorstwa prywatne (stąd zaobserwowany w ostatnich latach wzrost inwestycji z krajów rozwijających się). Zapewniony w ten sposób stały dopływ środków finansowych daje krajom afrykańskim możliwość swobodnego ustalania budżetów, bez obaw o finanse i problemów związanych z wycofaniem się inwestorów europejskich i amerykańskich.

Kraje przyjmujące inwestycje zainteresowane są głównie inwestycjami w produkcję przemysłową wymagającą dużych nakładów siły roboczej, co daje tak potrzebne miejsca pracy. Dobrym przykładem współpracy jest brazylijski holding Odebrecht, od 1984 r. obecny w Angoli, będący jednym z największych pracodawców w kraju. Odebrecht odpowiada tam za realizację wielu projektów inżynieryjno-budowlanych, a jego działania obejmują również rynek nieruchomości, produkcję biopaliw (Companhia de Bioenergia de Angola Ltda.) i wydobycie diamentów (Angola Mining Development Association, SDM i Catoca Mining Association $)^{11}$. Innym przykładem jest Lesotho. Korzystając z przyjętej w maju 2000 r. przez amerykański Kongres ustawy (African Growth and Opportunity Act, AGOA), Lesotho stało się największym subsaharyjskim dostawcą tekstyliów i odzieży do USA. Pierwszymi inwestorami w Lesotho były w latach 80. przedsiębiorstwa $\mathrm{z}$ RPA. W latach 90. dołączyli do nich inwestorzy z Tajwanu i Azji Południowo-Wschodniej. Dzięki korzystnym rozwiązaniom rządu sektor odzieżowy rozwijał się nieustannie, a Lesotho zostało „dżinsową stolicą Afryki”, produkując $26 \mathrm{mln}$ par spodni rocznie.

\section{Korzyści płynące z inwestycji}

Rosnące zainteresowanie inwestorów zagranicznych Afryką Subsaharyjską wynika z szeregu czynników. Przede wszystkim inwestorzy zyskują dostęp do licznych bogatych złóż surowców mineralnych, takich jak: ropa naftowa i gaz ziemny, miedź, boksyty, kobalt, srebro, złoto, uran, cyna, żelazo, diamenty, cynk, ołów, mangan, nikiel czy chrom. Kraje afrykańskie zwykle nie upierają się przy lokowaniu zakładów przetwórczych u siebie, zezwalając na wydobycie i wywóz surowców za granicę w celu ich przetworzenia. Koszty pracy w Afryce nadal pozostają niższe aniżeli w innych krajach rozwijających się, nawet azjatyckich. Inwestorzy chińscy doceniają

11 www.odebrecht.com (19.09.2010). 
elastyczność kontrahentów afrykańskich: brak wymagań odnośnie do zatrudnienia pracowników miejscowych i zgodę na sprowadzanie licznej siły roboczej z Chin. Istotne znaczenie ma także brak nacisków politycznych na Chiny w kwestii m.in. obrony praw człowieka.

Największą zaletą jest jednak dostęp do rynków zbytu krajów rozwiniętych dzięki porozumieniom międzynarodowym. African Growth and Opportunity Act daje bezcłowy dostęp do rynku Stanów Zjednoczonych towarom z 41 krajów Afryki Subsaharyjskiej do 2015 r. Podobnie inicjatywa Unii Europejskiej Everything But Arms (EBA), która weszła w życie w $2001 \mathrm{r}$. Zgodnie z nią towary pochodzące z najsłabiej rozwiniętych państw świata (większość to kraje Afryki Subsaharyjskiej) wyjęte zostały spod wszelkich ograniczeń celnych i ilościowych. Zarówno AGOA, jak i EBA sprawiają, że towary posiadające certyfikaty pochodzenia z większości państw Afryki są uprzywilejowane względem towarów wytworzonych w innych państwach rozwijających się. Najczęściej z porozumień tych korzystają inwestorzy chińscy oraz singapurscy.

Korzyści, jakie państwa afrykańskie odnoszą z inwestycji zagranicznych, są trudne do przecenienia. Inwestorzy, zarówno z krajów rozwiniętych, jak i rozwijających się, dają państwom goszczącym dostęp do swoich specjalistów i know-how, jak również swojego rynku wewnętrznego. Dostarczają kapitału tak potrzebnego ich gospodarkom, rozbudowują infrastrukturę, zwłaszcza drogową i portową. Szczególnie cenieni są inwestorzy chińscy, którzy poza kapitałem inwestycyjnym udostępniają kolejne środki finansowe w ramach pożyczek. Duże zainteresowanie inwestorów oznacza także lepsze warunki kontraktów. Inwestorzy z krajów rozwijających się mają dodatkowe zalety, których nie posiadają inwestorzy europejscy czy amerykańscy. Są nimi: elastyczność w odniesieniu do zmieniających się (na gorsze) warunków kontraktu, nieprzywiązywanie wagi do warunków politycznych w kraju, brak ingerencji w politykę wewnętrzną oraz nienarzucanie własnych standardów politycznych i etycznych.

Negatywne skutki inwestycji z krajów rozwijających się są analogiczne do zagrożenia niesionego przez inwestycje z krajów rozwiniętych: zagrożenie dominacją inwestora zagranicznego na rynku wewnętrznym czy wpływ polityczny, zwłaszcza w sytuacji, gdy właścicielem przedsiębiorstwa inwestującego jest obce państwo.

Koszty inwestycji w Afryce pozostają bardzo wysokie. Łączą się one z niedorozwojem infrastruktury, zwłaszcza transportowej, która zasadniczo utrudnia rozwój inwestycji. Dane liczbowe dla Afryki Subsaharyjskiej są wręcz katastrofalne: wskaźnik zagęszczenia dróg ( $\mathrm{km}$ dróg na $100 \mathrm{~km}^{2}$ ) w $2000 \mathrm{r}$. równy był $6,9 \mathrm{~km}$ (w regionie Azji Wschodniej i Pacyfiku w 2007 r. 46,9 km). W 2000 r. jedynie 12,1\% dróg Afryki Subsaharyjskiej było utwardzonych (70,8\% w regionie Azji Wschodniej i Pacyfiku 
w 2005 r.). Podobnie przedstawia się sytuacja w odniesieniu do sieci kolejowej, która wciąż pozostaje niedorozwinięta. W rezultacie koszty transportu na kontynencie są zdecydowanie zbyt wysokie: transport samochodu z Japonii do Wybrzeża Kości Słoniowej jest trzykrotnie tańszy aniżeli z Etiopii ${ }^{12}$.

\subsection{Pomoc na rzecz rozwoju}

Obok bezpośrednich inwestycji zagranicznych źródłem dodatkowych środków finansowych z zagranicy jest pomoc na rzecz rozwoju (Official Development Assistance, ODA). W początkowym okresie po dekolonizacji celem pomocy na rzecz rozwoju było zaspokojenie potrzeb humanitarnych, a także przyspieszenie szeroko rozumianego rozwoju gospodarczego i społecznego krajów przyjmujących. Pomoc finansowa z zagranicy miała umożliwić nowo powstałym państwom afrykańskim sprawne funkcjonowanie, czyli uruchomienie administracji państwowej, także sądownictwa i szkół oraz konstrukcję struktur niezbędnych do jego rozwoju: infrastruktury transportowej, energetycznej, zaopatrzenia w wodę. W miarę upływu czasu środki pomocowe były przeznaczane na pozostałe sektory i dziedziny życia: kulturę, naukę, ochronę środowiska, ale także współpracę wojskową.

Począwszy od lat 90., coraz większa część pomocy otrzymywanej przez kraje afrykańskie lokowana jest w podstawowych usługach społecznych, edukacji i ochronie zdrowia, czyli w sektorach, gdzie zwykle nie ma bezpośrednich inwestycji zagranicznych. Znacznie mniejsza niż w latach 90. jest natomiast alokacja środków pomocowych w produkcję przemysłową, łączność, a nawet rolnictwo. Duża część środków wykorzystywana jest do rozbudowy infrastruktury, dlatego ODA służy jako katalizator bezpośrednich inwestycji zagranicznych: dzięki wieloletniej pomocy w rozbudowie infrastruktury, kształceniu specjalistów i przeprowadzaniu niezbędnych reform kraje osiągają wystarczający poziom rozwoju gospodarczego, aby przyciągnąć wszelkiego rodzaju inwestycje.

Wielkość pomocy na rzecz rozwoju, jaką otrzymywały na przestrzeni ostatnich kilkudziesięciu lat kraje rozwijające się, uzależniona była od wielu czynników. Do najważniejszych możemy zaliczyć sytuację gospodarczą krajów przyjmujących i udzielających pomocy, jak również politykę zagraniczną poszczególnych państw i ugrupowań regionalnych, do których należały. Jak wynika z rysunku 12, Afryka Subsaharyjska już od końca lat 70. otrzymywała największy wolumen pomocy na rzecz rozwoju w porównaniu $\mathrm{z}$ innymi regionami rozwijającymi się. Pomoc dla tego regionu rosła nieprzerwanie do roku 1994, osiągając kwotę

12 African Economic Outlook 2010, AfDB/OECD 2010, s. 53. 
19,2 mld dol., po czym nastąpił spadek w latach 1995-2000. Szybki wzrost wskaźnika w latach 2001-2006 doprowadził do rekordowej kwoty wsparcia równej 40,9 mld dol. w 2006 r. i 40,1 mld dol. w 2008 r.

Rysunek 12. Pomoc na rzecz rozwoju udzielona regionom rozwijającym się (w mld dol., 1960-2008)

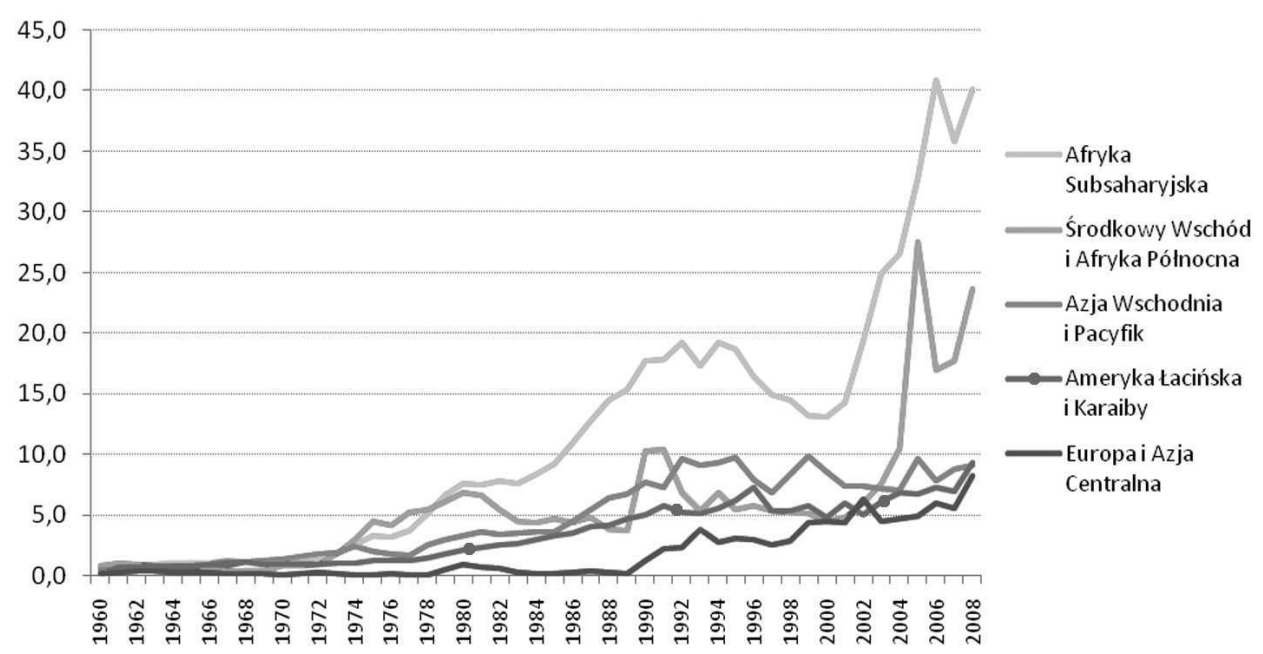

Źródło: opracowanie własne na podstawie World Development Indicators Banku Światowego.

Warto podkreślić, iż pomoc, jaką otrzymały w tym czasie pozostałe kraje rozwijające się, była znacznie mniejsza. Najwyższa wartość pomocy uzyskanej przez Środkowy Wschód i Afrykę Północną to niemal połowa wsparcia przyznanego wówczas Afryce Subsaharyjskiej (27,5 mld dol.), a kolejny rok przyniósł spadek do 16,9 mld dol. Pozostałe regiony nigdy nie przekroczyły kwoty $10 \mathrm{mld}$ dol.

Różna jest waga pomocy dla poszczególnych państw afrykańskich. Udział otrzymanych środków w wartości dodanej wskazuje nie tylko na wartość samej pomocy, ale także wkład do rozwoju gospodarczego państwa. W 2008 r. Liberia otrzymała ODA równą aż 143\% PKB, stanowiącą część programów pomocowych uruchomionych po wojnie wewnętrznej w latach 1999-2003. Kolejny kraj, Burundi, otrzymał pomoc równą już „tylko” 43\% PKB. W przypadku Gwinei Bissau udział ODA równy był 30,6\% PKB, za nią były Wyspy Świętego Tomasza i Książęca (26,9\% PKB), Malawi (21,4\% PKB), Ruanda (20,9\% PKB), Mozambik (20,5\% PKB) i Sierra Leone $(18,8 \% \mathrm{PKB})$. 


\section{Rysunek 13. Pomoc na rzecz rozwoju udzielona Afryce Subsaharyjskiej (2008)}

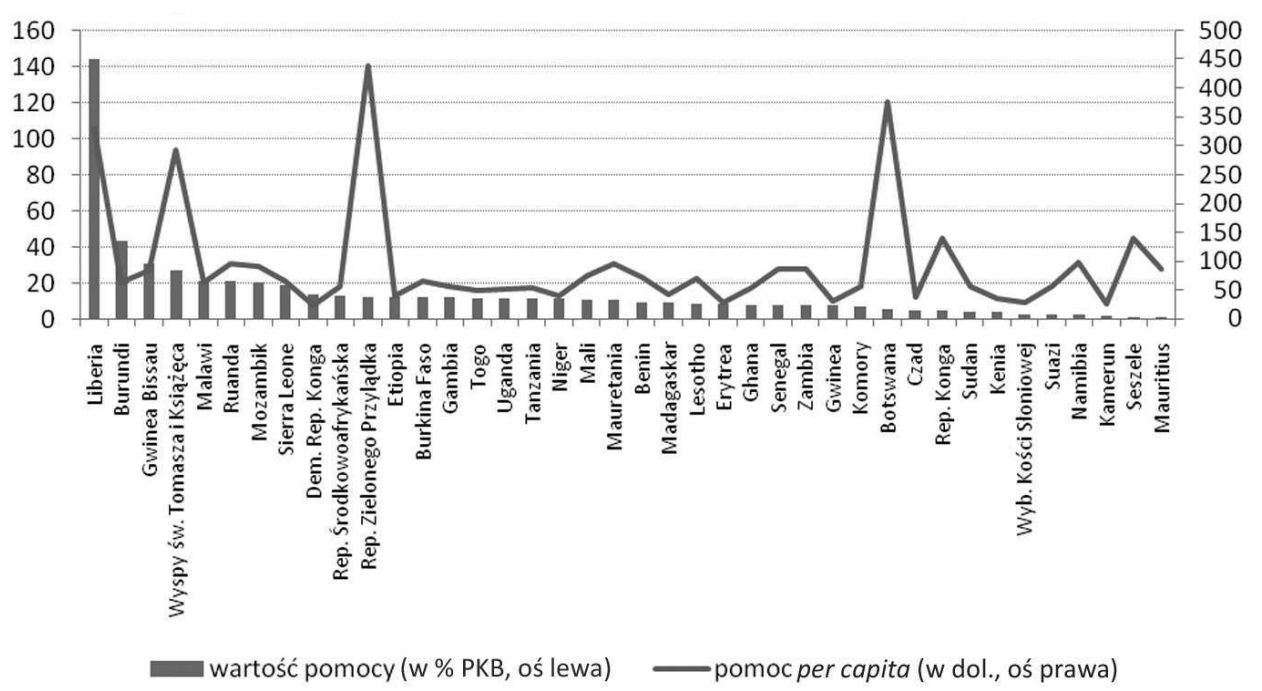

Źródło: opracowanie własne na podstawie World Development Indicators Banku Światowego.

Do grupy krajów o wysokiej pomocy per capita należą Republika Zielonego Przylądka (438,2 dol.), Botswana (376 dol.), Liberia (330 dol.), Wyspy Świętego Tomasza i Książęca (292,2 dol.), Seszele i Republika Konga (po 140 dol.).

Istotną częścią wsparcia ze strony krajów rozwiniętych jest umorzenie długów krajów rozwijających się. Było to widoczne zwłaszcza w latach 2005 i 2006, kiedy wartość pomocy osiągnęła rekordową wysokość. Miały wówczas miejsce poważne operacje oddłużenia niektórych państw afrykańskich (m.in. Nigerii, która w 2005 r. otrzymała ODA wielkości 6,4 mld dol.). W ostatnich latach obserwuje się tendencję do ograniczenia wykorzystania oddłużenia jako formy pomocy. Nastąpił także wzrost pomocy humanitarnej.

Wśród dawców ODA najważniejszą rolę odgrywają kraje członkowskie Komitetu Pomocy Rozwojowej OECD (Development Assistance Committee). Poza tym Afryka Subsaharyjska uzyskuje także wsparcie od takich państw, jak: Chiny, Brazylia, Indie, Malezja czy Rosja. Szczególne miejsce Chin wynika z zainteresowania surowcami, jakie posiada Afryka, choć nie ma dowodów na wyróżnianie we współpracy krajów bogatych w zasoby naturalne ${ }^{13}$.

\footnotetext{
${ }^{13}$ Ibidem, s. 44 i nast.
} 


\subsection{Przekazy pieniężne od emigrantów}

Niezwykle ważną rolę w finansach krajów Czarnej Afryki odgrywają przekazy pieniężne od emigrantów. Według danych ONZ (Population Division, the UN Department of Economic and Social Affairs) w 2009 r. na świecie żyło ponad 18 mln emigrantów z Afryki Subsaharyjskiej ${ }^{14}$. Wielu z nich pochodziło z Mali, Burkiny Faso, Ghany, Erytrei, Nigerii, Mozambiku, Zimbabwe, RPA, Sudanu i Demokratycznej Republiki Konga. Większość emigrantów pozostawała na kontynencie afrykańskim (63,2\% w 2005 r.), a ci, którzy kierowali się za granicę, zwykle trafiali do krajów rozwiniętych: członków OECD $\left(25,2 \%\right.$ w 2005 r.) lub pozostałych $(2,9 \%)^{15}$.

Przyczyny, dla których mieszkańcy Czarnej Afryki decydują się na emigrację, są różne: do najczęstszych należy poszukiwanie pracy, lepszego życia, lepszych warunków kształcenia, ale także ucieczka przed konfliktem zbrojnym i zagrożeniem życia. Część udaje się za granicę w celu utrzymania pozostawionej w kraju rodziny.

Innym aspektem zagadnienia jest migracja regionalna. Szacuje się, że w 2009 r. w Afryce Subsaharyjskiej przebywało około $18 \mathrm{mln}$ imigrantów. Największym zainteresowaniem migrujących cieszy się RPA, w której kopalniach zatrudnienie znajdują najczęściej obywatele państw sąsiadujących. Ważnymi krajami przyjmującymi imigrantów są również Wybrzeże Kości Słoniowej, Ghana, Nigeria i Etiopia. Uchodźców z zagrożonych konfliktem terenów przyjmują Kenia, Uganda, Czad i Tanzania.

Środki finansowe przekazywane przez emigrantów z Afryki Subsaharyjskiej stanowią jedynie niewielką część całości przekazów finansowych emigrantów świata (6,8\% w 2009 r.). W roku tym do Afryki Subsaharyjskiej trafiło łącznie 20,8 mld dol. w ramach przekazów od emigrantów, podczas gdy kraje o niskim i średnim dochodzie otrzymały razem 306 mld dol. Należy jednak podkreślić, iż jeszcze w 1992 r. wielkość przekazów do Czarnej Afryki była ponad dziesięciokrotnie niższa (2,1 mld dol.).

Środki finansowe z zagranicy nie przyczyniły się istotnie do wzrostu wartości dodanej regionu, stanowiły bowiem w 2009 r. jedynie 2,5\% PKB Afryki Subsaharyjskiej. Inaczej przedstawia się sytuacja w przypadku poszczególnych państw. Jak wskazuje rysunek 14, przekazy finansowe od emigrantów stanowią istotną część budżetów domowych rodzin pozostawionych w kraju. Jest to szczególnie widoczne w przypadku Lesotho, gdzie w 2008 r. przekazy stanowily aż $27,3 \%$ PKB, a badania wykazały, że liczba osób żyjących w ubóstwie wzrosłaby o 15\%, gdyby zabrakło pomocy emigrantów. Do grupy krajów o dużym udziale przekazów w dochodzie

14 Dane za: International Migration 2009, Population Division, the UN Department of Economic and Social Affairs, www.un.org (25.10.2010).

15 Sub-Saharian Africa, Migration and Remittances Factbook, Migration and Remittances Team, Development Prospects Group, World Bank, www.worldbank.org (25.10.2010). 
należą również Senegal (9,7\%), Gambia (8,2\%), Togo (8,1\%), Republika Zielonego Przylądka (8\%), Liberia (7,9\%), Sierra Leone (7,7\%) i Gwinea Bissau (7\%). Porównanie wolumenu przekazów w latach 2008 i 2009 pokazuje jedynie nieistotne różnice.

Rysunek 14. Przekazy finansowe emigrantów (w \% PKB, 2008-2009)

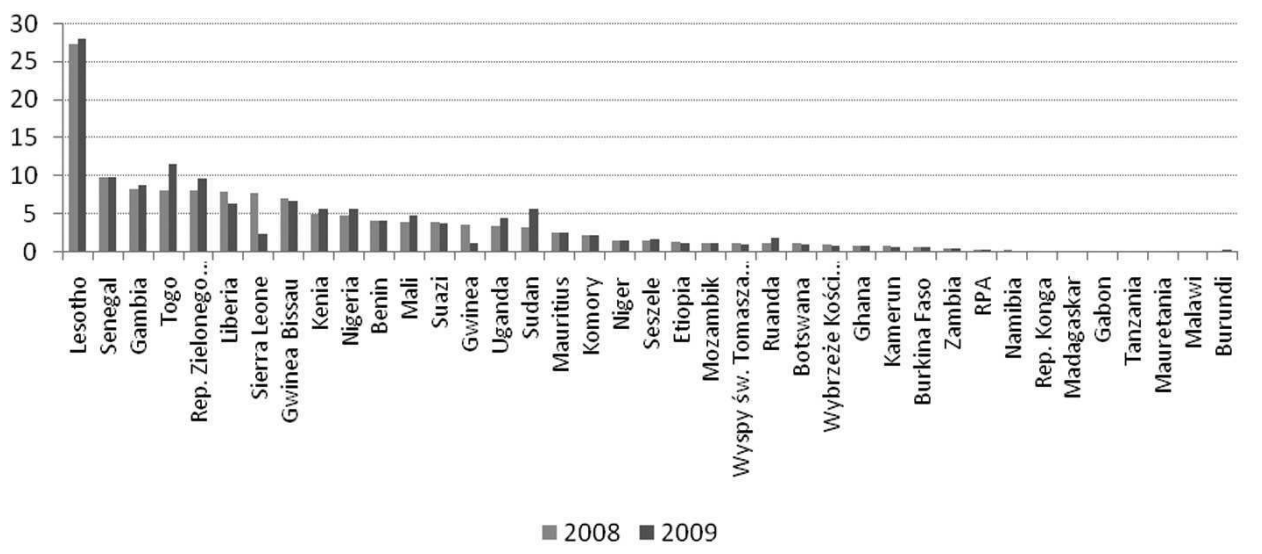

Źródło: opracowanie własne na podstawie World Development Indicators Banku Światowego.

Przekazy od emigrantów były jeszcze do niedawna niedocenianą formą wsparcia, wywierającą jednak coraz większy wpływ na gospodarki państw afrykańskich. Fundusze zarobione za granicą pomagają całym rodzinom wyjść z kręgu biedy, kreują popyt na rynku lokalnym, wykorzystywane są również do rozwoju sektora prywatnego: powracający do kraju emigranci zwykle uruchamiają prywatną działalność gospodarczą, tworząc nowe miejsca pracy i dokładając się do budżetów lokalnych (podatki). Badania Komisji Gospodarczej ds. Afryki Narodów Zjednoczonych (UN Economic Commission for Africa, UNECA) wykazały, że przekazy mają także znaczący wpływ, zarówno pozytywny, jak i negatywny na społeczności państw odbierających ${ }^{16}$. Pozytywnym przykładem może być Zimbabwe, gdzie dzieci z rodzin wspieranych przez emigrantów osiągają lepsze wyniki w szkole, czy RPA, gdzie wzrosła liczba dzieci kończących edukację podstawową i średnią. Negatywny wpływ przekazów przejawia się natomiast w spadku odpowiedzialności i zaradności rodzin otrzymujących wsparcie z zagranicy, z których część, po ustaniu pomocy, ponownie wpada w ubóstwo ${ }^{17}$. Także pozytywny efekt emigracji, jakim jest spadek bezrobocia, może

\footnotetext{
${ }^{16}$ www.uneca.org (25.10.2010).

17 A. Lindley, African Remittances and Progress: Opportunities and Challenges, Real Instituto Elcano, "ARI" 2008, Nr 52, s. 3.
} 
obrócić się na niekorzyść: rządy państw otrzymujących przekazy z zagranicy często odwlekają w czasie niezbędne reformy, zmylone brakiem niepokojów społecznych.

Należy jednak pamiętać, że ujęte w statystykach wielkości są jedynie wierzchołkiem góry lodowej. Prawdopodobna wielkość transferów jest znacznie wyższa, są one jednak dokonywane poza oficjalnymi kanałami, stąd niemożność ich dokładnego oszacowania.

\section{Handel}

Afryka Subsaharyjska, podobnie jak inne regiony świata, odnotowała wzrost wolumenu wymiany towarowej w latach 2003-2008, jednak jej udział w handlu światowym pozostał niewielki (około 3\%). Słaby wynik jest rezultatem wciąż obowiązujących barier handlowych broniących towarom afrykańskim dostępu do rynków europejskich czy amerykańskich. Sytuację pogorszył jeszcze ogólnoświatowy kryzys, który skłonił kraje rozwinięte do wzmocnienia barier chroniących ich rynki wewnętrzne.

Przyczyną niskiego udziału Afryki Subsaharyjskiej w handlu światowym jest fakt, iż eksport państw afrykańskich jest mało zróżnicowany, o niskim poziomie przetworzenia: w $80 \%$ stanowią go ropa naftowa, surowce mineralne oraz (w niewielkim stopniu) produkty rolne, w tym żywność. Dlatego spadek cen ropy naftowej, jaki miał miejsce w 2008 r., spowodował duże problemy finansowe państw afrykańskich.

\section{Rysunek 15. Struktura eksportu państw Afryki Subsaharyjskiej (w \%)}

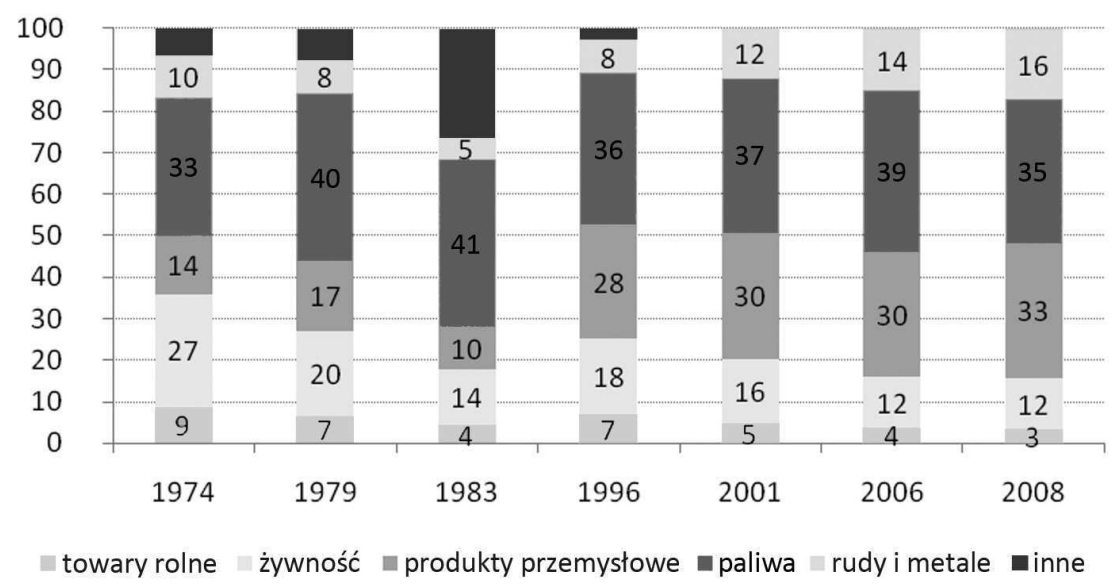

Źródło: opracowanie własne na podstawie World Development Indicators Banku Światowego. 
Większość państw Afryki pozostaje eksporterami wąskiej grupy towarów, $\mathrm{w}$ większości surowców mineralnych (ropa naftowa i gaz ziemny, drewno, rudy) ${ }^{18}$. Do najważniejszych eksporterów ropy naftowej zaliczamy Nigerię (91,7\% eksportu w 2008 r.), Angolę (b.d.), Sudan (94,4\%), Kamerun (61,6\%), Wybrzeże Kości Słoniowej (36,9\%), Mauretanię (21,7\%), Senegal (24\%) i Mozambik (17,5\%) ${ }^{19}$. Rudy i metale zajmują ważne miejsce w eksporcie m.in. Zambii $(81,1 \%$, miedź, kobalt, srebro), Nigru (68,5\%, złoto, uran, cyna), Mauretanii (60\%, żelazo), Mozambiku (57,3\%, boksyty), Namibii (31,3\%, diamenty, uran, cynk, ołów, złoto, miedź), RPA (29,3\%, diamenty, żelazo, mangan, nikiel, chrom, srebro), Ruandy ( $28 \%$, cyna) czy Botswany $\left(19,6 \%\right.$, diamenty, nikiel, miedź) ${ }^{20}$. Żywność stanowi ważną pozycję w eksporcie Wysp Świętego Tomasza i Książęcej (92,4\%), Malawi (85,8\%), Etiopii (77,5\%), Republiki Zielonego Przylądka (72,6\%), Ruandy (66,4\%), Burundi (64,8\%), Ghany (63,5\%), Ugandy (62,3\%), Seszeli (58,5\%), Gambii (53\%), Kenii (44,2\%), Wybrzeża Kości Słoniowej (40,6\%), Tanzanii (35,5\%), Senegalu (29,5\%), Namibii $(22,5 \%)$ i Mauritiusa (22,1\%). Produkty przetworzone eksportują głównie Republika Zielonego Przylądka (72,6\%), Suazi (70\%), Burundi (64,8\%), Togo (62,2\%), RPA (47,5\%), Kenia (44,2\%), Zimbabwe (34,3\%), Senegal (29,5\%), Madagaskar (28,8\%), Uganda $(27,4 \%)$, Namibia (22,5\%) i Mauritius (22,1\%). Rysunek 16 przedstawia wzrost eksportu i importu produktów przetworzonych $\mathrm{w}$ regionie subsaharyjskim w latach 1960-2009.

\section{Rysunek 16. Eksport i import produktów przetworzonych w Afryce Subsaharyjskiej} (w mld dol., 1960-2009)

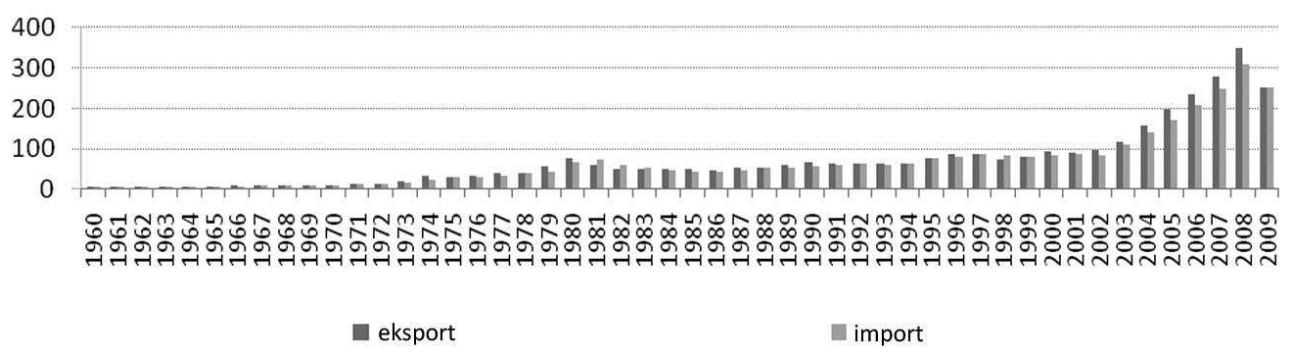

Źródło: opracowanie własne na podstawie World Development Indicators Banku Światowego.

\footnotetext{
18 Jeżeli przynajmniej 10\% PKB pochodzi z primary commodities rent, wówczas kraj klasyfikowany jest jako gospodarka oparta na surowcach (resource rich, natural resource economy).

19 Dane za 2009 r.

20 Dane za lata 2008-2009.
} 
Zależność Afryki od surowców mineralnych i niska dywersyfikacja eksportu niosą wrażliwość na zmiany cen tychże surowców na rynkach światowych i idące za tym zmiany popytu. Wziąwszy pod uwagę fakt, iż od lat 70. światowe ceny surowców naturalnych wykazują tendencje spadkowe, przekłada się to na brak stabilności wzrostu większości państw Afryki, nawet przy wzrastającym wolumenie eksportu.

Te negatywne tendencje wyhamował wzrost popytu na surowce mineralne, zwłaszcza energetyczne, ze strony przedsiębiorstw chińskich. Współpraca chińsko-afrykańska przyniosła odwrócenie dotychczasowych negatywnych tendencji i poprawę wyników finansowych eksporterów afrykańskich.

Rysunek 17. Udział handlu w wartości dodanej (w \% PKB, 2009)

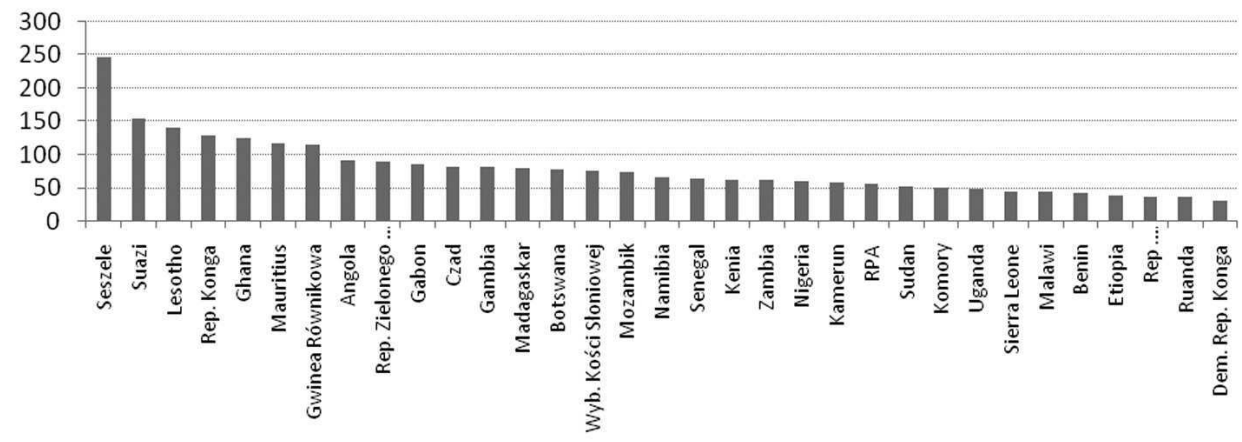

Źródło: opracowanie własne na podstawie World Development Indicators Banku Światowego.

W okresie 1995-2010 udział handlu zagranicznego w PKB wzrastał zarówno w krajach bogatych surowcowo, jak i pozbawionych istotnych zasobów mineralnych. Jak wskazują dane, wzrost udziału eksportu w krajach eksportujących głównie ropę naftową następował jednak znacznie szybciej niż w pozostałych.

Przeszkodą w rozwoju handlu jest słaba infrastruktura transportowa: brak dróg i autostrad, połączeń kolejowych, jak również słaba jakość istniejącej sieci drogowej. Sytuacji nie poprawia niestabilna sytuacja polityczna w wielu krajach i ciągłe zagrożenie konfliktem zbrojnym. Brakuje również regionalnych porozumień handlowych, które usprawniłyby przepływ towarów.

W wielu krajach Afryki Subsaharyjskiej w ostatnich latach zostały wprowadzone automatyczne systemy odpraw celnych, m.in. w Ghanie, Kenii i Tanzanii. Zwykle takie usprawnienie diametralnie poprawia sytuację, skracając czas odpraw, jednak częste braki w dostawach prądu i brak dostępu do szybkich łączy internetowych niwelują uzyskane korzyści i uniemożliwiają korzystanie z innowacji. Utrudnieniem w rozwoju współpracy z zagranicą są także liczne obciążenia administracyjne 
i wymagania sanitarne, zmuszające eksporterów i importerów do wypełniania obszernej dokumentacji lub zdobywania niezliczonej liczby certyfikatów. Sytuację komplikują nieprzejrzyste procedury celne i powszechna korupcja. Przykładem może być Erytrea, gdzie na dopełnienie wszystkich formalności eksportowych potrzeba około 50 dni i średnio 1431 dol. Koszty transportu podnoszą również blokady częste na drogach i autostradach. Liczne bariery handlowe zawyżają koszty transakcji, a wszystkim tym utrudnieniom sprzyja niewydolność administracyjna i biurokracja.

\section{Polityka rządów}

Kluczowe znaczenie dla zapewnienia wzrostu gospodarczego ma odpowiedzialna polityka fiskalna. Większość gospodarek państw Afryki Subsaharyjskiej jest oparta na posiadanych złożach surowców naturalnych, których ceny podlegają częstym zmianom. W konsekwencji polityka fiskalna niektórych krajów uzależniona jest od cen tychże surowców, co z kolei prowadzi do realnej groźby destabilizacji budżetu państwa w przypadku ich obniżenia. W szczególnie trudnym położeniu znajdują się kraje eksportujące ropę naftową lub inne surowce mineralne (diamenty, złoto), których gospodarki są w większości oparte na wpływach z eksportu tychże surowców. Do takich państw należy Nigeria, której 98,2\% eksportu stanowią surowce energetyczne, a także Sudan (89,8\%), Gabon (85,6\%) czy Angola, intensywnie rozwijająca produkcję ropy naftowej (od 2007 r. jest członkiem OPEC), której przychody z tytułu eksportu ropy stanowią $80 \%$ budżetu i $45 \%$ PKB $(2005)^{21}$.

Innym wyzwaniem dla polityki budżetowej rządów afrykańskich jest otrzymywana z zagranicy pomoc na rzecz rozwoju. Dodatkowe środki finansowe wspierają rząd w realizacji polityki fiskalnej, mogą jednak skłaniać do nadmiernych wydatków i przyczyniać się do destabilizacji budżetu. Za pozytywny aspekt pomocy na rzecz rozwoju należy uznać fakt, iż zwykle jej wielkość pozostaje nieznana a priori, co chroni kraje przed przesadnymi wydatkami i każe zabezpieczyć się na wypadek braku środków.

Mimo dowodów, iż czynniki geograficzne mają determinujący wpływ na wzrost gospodarczy, przykłady empiryczne nie zawsze potwierdzają prawdziwość tego twierdzenia. W niektórych przypadkach kraje o podobnych uwarunkowaniach geograficznych i zasobach naturalnych rozwijały się w odmienny sposób, w zależności od podejmowanych decyzji politycznych. Botswana i Zambia posiadają duże zasoby

\footnotetext{
${ }^{21}$ Angola: towards an energy strategy, International Energy Agency, OECD 2006, s. 19.
} 
surowców mineralnych (odpowiednio diamenty i miedź) i leżą w głębi kontynentu. Mimo początkowo podobnych warunków wyjściowych (zbliżone wartości PKB per capita w latach 1960-1978) Botswana znajduje się w grupie państw o średnim dochodzie, a Zambia - o najniższym. W obu państwach gospodarki oparte zostały na eksporcie posiadanych surowców, który zapewnia około $80 \%$ wpływów z eksportu Botswany oraz Zambii.

Rysunek 18. PKB per capita (w dol., 1960-2008)

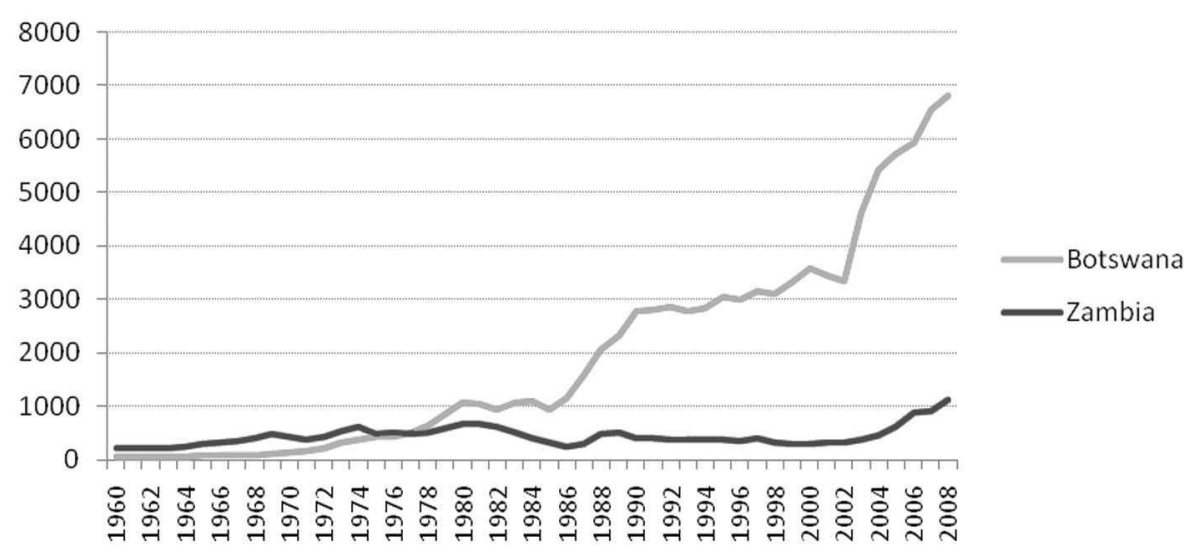

Źródło: opracowanie własne na podstawie World Development Indicators Banku Światowego.

Rysunek 19. PKB per capita (w dol., 1960-2008)

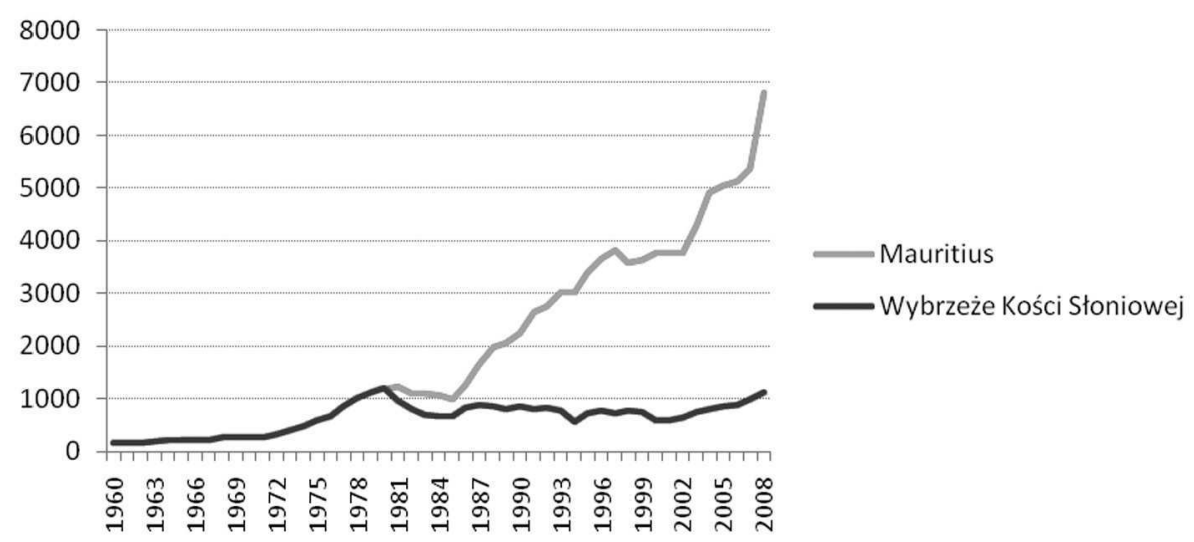

Źródło: opracowanie własne na podstawie World Development Indicators Banku Światowego. 
Podobnie w przypadku Mauritiusa i Wybrzeża Kości Słoniowej. Oba kraje mają dostęp do morza (oceanów), a ich gospodarki początkowo opierały się głównie na produkcji rolnej. Jednak Mauritius rozwinął sektor turystyczny, który przyciągnął znaczne inwestycje zagraniczne, tymczasem Wybrzeże Kości Słoniowej od 1993 r. boryka się z poważnym konfliktem wewnętrznym, który skutecznie hamuje wzrost gospodarczy kraju.

W obu przypadkach siła oddziaływania czynników surowcowych okazała się słabsza od innych determinantów (decyzji politycznych, konfliktu zbrojnego).

\section{Rozwój sektora prywatnego}

Większość państw afrykańskich podejmuje liczne wysiłki w celu poprawy swojej sytuacji makroekonomicznej. Istotnym czynnikiem warunkującym wzrost gospodarczy jest rozwinięty sektor prywatny, dlatego też kraje Afryki Subsaharyjskiej wprowadzają szerokie programy reform oraz zachęcają do inwestycji.

W raporcie Banku Światowego Doing Business 2011 ocenianych jest 9 wskaźników, które klasyfikują kraje pod względem sprzyjania przedsiębiorcom na miejscu od 1 do 183. W najnowszym raporcie, opublikowanym w listopadzie 2010 r., Afryka Subsaharyjska zajęła ostatnie miejsce wśród regionów rozwijających się, ze średnim miejscem 137 (od 1 do 183). Najlepiej wśród państw afrykańskich wypadł Mauritius, zajmując 20 pozycję, za nim RPA (34), Botswana (52) i Ruanda (58). Większość państw Afryki Subsaharyjskiej zajmuje odległe pozycje i zamyka ww. listę.

Na podstawie rankingu Bank Światowy przygotował listę 10 państw, które podjęły największe wysiłki w celu poprawy środowiska inwestycyjnego. Na liście tej znajdują się aż 3 państwa afrykańskie: Ruanda, Republika Zielonego Przylądka i Zambia, odpowiednio na drugiej, piątej i siódmej pozycji.

Mimo kryzysu i trudnej sytuacji finansowej wiele państw podjęło starania w celu poprawy możliwości prowadzenia działalności gospodarczej. Dobre regulacje prawne nie tylko pomagają w zdobyciu wzajemnego zaufania między inwestorami i krajami goszczącymi inwestycje, ale także pozwalają przedsiębiorstwom przetrwać w sytuacji kryzysu. Zgodnie z rankingiem Banku Światowego spośród 46 państw Afryki Subsaharyjskiej aż 27 krajów podjęło w latach 2009-2010 szereg reform mających na celu zwiększenie konkurencyjności na rynku światowym oraz zachęcenie do powstawania nowych przedsiębiorstw i nowych miejsc pracy. Państwa te w przeważającej większości skupiły swe wysiłki na uproszczeniu procedur koniecznych do rozpoczęcia działalności gospodarczej i wzmożeniu wymiany z zagranicą. Często podjęte przez 
państwa reformy różnych dziedzin się uzupełniają, a ich efekty widoczne są także w innych sektorach, np. w spadku szarej strefy.

Tabela 2. Główni reformatorzy w latach 2009-2010

\begin{tabular}{|c|c|c|c|c|c|c|c|c|c|}
\hline & 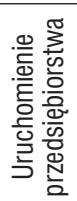 & 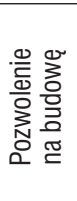 & 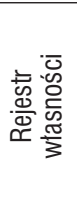 & 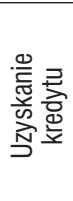 & 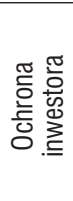 & 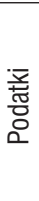 & 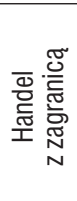 & 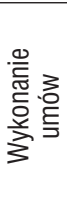 & 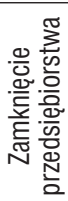 \\
\hline Kazachstan & $\checkmark$ & $\checkmark$ & & & $\checkmark$ & & $\checkmark$ & & \\
\hline Ruanda & & $\checkmark$ & & $\checkmark$ & & & $\checkmark$ & & \\
\hline Peru & $\checkmark$ & $\checkmark$ & $\checkmark$ & & & & $\checkmark$ & & \\
\hline Wietnam & $\checkmark$ & $\checkmark$ & & $\checkmark$ & & & & & \\
\hline $\begin{array}{l}\text { Rep. Zielonego } \\
\text { Przylądka }\end{array}$ & $\checkmark$ & & $\checkmark$ & & & $\checkmark$ & & & \\
\hline Tadżykistan & $\checkmark$ & & & & $\checkmark$ & $\checkmark$ & & & \\
\hline Zambia & $\checkmark$ & & & & & & $\checkmark$ & $\checkmark$ & \\
\hline Węgry & & $\checkmark$ & $\checkmark$ & & & $\checkmark$ & & & $\checkmark$ \\
\hline Grenada & $\checkmark$ & & $\checkmark$ & & & & $\checkmark$ & & \\
\hline Brunei Darussalam & $\checkmark$ & & & & & $\checkmark$ & $\checkmark$ & & \\
\hline
\end{tabular}

Źródło: Doing Business 2011. Making a Difference for Entrepreneurs, The World Bank and the International Finance Corporation 2010, s. 5.

Państwa Afryki Subsaharyjskiej skupiły swe wysiłki na uproszczeniu procedur rozpoczęcia działalności gospodarczej (6 państw), promocji współpracy z zagranicą (9) i ułatwieniach podatkowych (9). Odnotowane zostały także przypadki działania na szkodę inwestorów: utrudnienia w rozpoczęciu działalności gospodarczej (2) i zwiększenie podatków (3) 22 . Przykładem może być Kenia, gdzie niektóre inwestycje, np. budowa magazynu, wymagają uprzedniego otrzymania pozwoleń środowiskowych, a koszt uzyskania samego pozwolenia na budowę wzrósł czterokrotnie. Tanzania nakazała przeprowadzenie badań geologicznych przed rozpoczęciem każdej nowej budowy, co wydłużyło czas uzyskania pozwolenia na budowę średnio o 20 dni ze względu na niedostateczną liczbę specjalistów będących w stanie zrealizować badania ${ }^{23}$.

22 Doing Business 2011. Making a Difference for Entrepreneurs, The World Bank and The International Finance Corporation 2010, s. 134-143.

${ }^{23}$ Doing Business 2010, The World Bank and the International Finance Corporation, Palgrave Macmillan 2010, s. 20. 
Koszty wprowadzanych reform stanowią obciążenie dla gospodarek państw afrykańskich, z czasem jednak przynoszą trudne do pominięcia oszczędności. Warto nadmienić, że koszty te różnią się w zależności od kraju: wprowadzenie „jednego okienka” dla rozpoczęcia działalności gospodarczej w Burkina Faso kosztowało jedynie 200 tys. dol., przynosząc zyski wielkości 1,7 mln dol. rocznie. W tym czasie przeprowadzenie podobnej reformy w Azerbejdżanie pochłonęło $5 \mathrm{mln}$ dol., w zamian dając oszczędności rzędu 8,4 mln dol. rocznie ${ }^{24}$.

Większość państw najszybciej reformujących swoje gospodarki powołała do życia specjalne komitety raportujące bezpośrednio premierowi lub prezydentowi, w pozostałych krajach komitety te pozostają pod zwierzchnictwem odpowiednich ministrów. W Ruandzie, Sierra Leone oraz Liberii przed rozpoczęciem procesu reform władze informowały o swoich zamierzeniach w kampaniach reklamowych organizowanych w prasie i na stronach internetowych. Nadzór nad procesem zwykle skutkował większą skutecznością podjętych działań.

\subsection{Reformy}

W ostatnich latach w największym stopniu swoje procedury reformowała Ruanda, w której m.in. uproszczeniu uległ proces zakładania przedsiębiorstwa i zatrudnienia pracowników. W rezultacie podjętych działań skróceniu uległ czas oczekiwania na pozwolenie na budowę, a opłaty urzędowe zostały zmniejszone. W $2010 \mathrm{r}$. wzrosła dostępność kredytów. Uproszczone zostały procedury celne poprzez ograniczenie liczby dokumentów wymaganych do odprawy i wspólne odprawy ze służbami sąsiadujących państw. Rząd Ruandy podjął także reformy w mało popularnych dziedzinach, jak ochrona inwestorów czy zakończenie działalności gospodarczej.

W porównaniu z Ruandą władze Republiki Zielonego Przylądka przeprowadziły niewiele zmian, jednak te, które zostały wdrożone, w istotny sposób przyczyniły się do poprawy klimatu gospodarowania. Ułatwiono rozpoczęcie działalności gospodarczej, rezygnując z niezbędnej dotąd kontroli władz lokalnych, a także komputeryzując system wydawania licencji. Ponadto obniżone zostały opłaty za rejestrację własności z 2\% wartości nieruchomości do opłaty stałej w wysokości 256 dol. ${ }^{25}$ Likwidacji uległy wszystkie opłaty skarbowe.

Trzeci najbardziej zaangażowany w reformowanie kraj afrykański to Zambia, której rząd zniósł obowiązkowe minima kapitałowe potrzebne do podjęcia działalności gospodarczej i wprowadził system ,jednego okienka”. W celu rozwoju handlu

\footnotetext{
${ }^{24}$ Ibidem, s. 3.

${ }^{25}$ Doing Business 2011, op.cit., s. 33 i 135.
} 
z sąsiadującym Zimbabwe skrócono czas oczekiwania na odprawę celną, umożliwiając składanie deklaracji celnej przez internet. Na przejściach granicznych pojawiły się nowoczesne skanery, dodatkowo przyspieszając odprawę. Rząd Zambii przyczynił się także do poprawy wykonania umów poprzez wprowadzenie swobodnego dostępu do danych sądowych i bazy aktów prawnych ${ }^{26}$.

Poza wyróżnionymi w ostatnim raporcie Banku Światowego państwami należy zwrócić także uwagę na inne kraje, które wprowadzają zmiany już od pewnego czasu. Należy do nich m.in. Liberia, której rząd przyjął w 2007 r. program reform, realizowany w kolejnych latach. Jedną z pierwszych zmian była rezygnacja z konieczności uzyskania licencji środowiskowej dla przedsiębiorstw prowadzących działalność gospodarczą. Zredukowana została opłata za nowo budowane budynki z 3\% wartości budynku oraz opłaty na rzecz Ministerstwa Prac Publicznych do 4 centów od stopy kwadratowej powierzchni budynku. Ministerstwo Finansów uprościło także dokumentację niezbędną do uzyskania pozwolenia na budowę. Poprawił się dostęp do usług użyteczności publicznej: po raz pierwszy od zakończenia konfliktu wewnętrznego Liberia Telecommunications Corporation jest w stanie zapewnić przyłączenie do sieci telefonicznej. Spadły także ceny generatorów ${ }^{27}$.

W Burkina Faso skróceniu o dwa miesiące uległ czas oczekiwania na pozwolenie na budowę, zmniejszyły się też o ponad połowę koszty otrzymania pozwolenia, a Narodowy Urząd Wody i Ścieków skrócił czas oczekiwania na przyłączenie do wodociągu o $35 \mathrm{dni}^{28}$. Także w zakresie rejestracji własności osiągnięcia były znaczące: Burkina Faso przesunęła się o 50 pozycji w rankingu Banku Światowego (z 163 pozycji w raporcie z $2009 \mathrm{r}$. na $114 \mathrm{w} 2010 \mathrm{r}$.), skracając czas potrzebny do rejestracji z 182 dni w raporcie z 2008 r., poprzez 136 dni w 2009 r., do 59 dni w 2010 r. Liczba wymaganych procedur zmniejszyła się z 8 do 4 , wprowadzono także limit czasowy procesu rejestracji. W celu uniknięcia możliwych niedoszacowań wprowadzone zostały tablice wartości nieruchomości. W przedmiocie wykonania umów rząd w Ouagadougou ograniczył opłaty sądowe, rezygnując z opłaty procentowej od wartości kontraktu na rzecz opłaty standardowej w wysokości około 12 dol.

Władze Mali wprowadziły system ,jednego okienka”, łącząc cztery procedury konieczne do otwarcia działalności gospodarczej w jedną. Zrezygnowano ze zróżnicowanych opłat za rejestrację firm na rzecz jednej opłaty w stałej wysokości. Poprawił się dostęp do usług użyteczności publicznej, m.in. poprzez skrócenie czasu oczekiwania na przyłączenie do wodociągu o miesiąc ${ }^{29}$. Rząd przyjął nowy kodeks

\footnotetext{
26 Ibidem, s. 143.

27 Doing Business 2010, op.cit., s. 18.

28 Ibidem, s. 20.

29 Ibidem.
} 
postępowania cywilnego, który wzmocnił ochronę inwestorów, dając udziałowcom dostęp do wewnętrznych informacji przedsiębiorstwa w celu ustalenia odpowiedzialności dyrektorów. Także w zakresie wykonania umów wprowadzone zostały znaczne zmiany: ograniczeniu uległy procedury i o 7 dni skrócono czas oczekiwania na decyzję sądu, uproszczono procedury przesłuchania świadków i zwiększono liczbę sędziów sądu handlowego, dzięki czemu średni czas rozprawy to 240 dni (315 dni jeszcze w 2008 r.).

W Mauritiusie wprowadzone zostały istotne zmiany w sferze zatrudnienia: uproszczeniu uległy procedury zwolnień, a urlop obowiązkowy wydłużony został do 22 dni roboczych. Jednak największe zmiany zostały dokonane w rejestracji własności, dzięki którym Mauritius przesunął się o 63 pozycje w rankingu Banku Światowego (z 131 w raporcie z 2009 r. na 66 w 2010 r.). Zmiany były rzeczywiście znaczące: rejestr własności został całkowicie skomputeryzowany, wyznaczono limity czasowe procesu rejestracji, skracając tym samym dotychczasowy okres oczekiwania o 6 miesięcy (z 210 dni do 26). Rząd Mauritiusa dostosował regulacje prawne do oczekiwań rynku i zezwolił na tworzenie prywatnych biur kredytowych o szerokich możliwościach działania. Zmienione zostały zasady rozliczeń podatkowych: $\mathrm{z}$ progów podatkowych na rzecz jednej wysokości podatku z szerszą bazą podatkową. Administracja fiskalna została zredukowana i skomputeryzowana. W styczniu 2009 r. przy Sądzie Najwyższym Mauritiusa powstał pierwszy sąd handlowy, w którym orzekają dwaj sędziowie Sądu Najwyższego. W ciągu pierwszych 5 miesięcy działania sądu handlowego Sąd Najwyższy przekazał mu do rozpatrzenia 593 z 959 spraw, jakie otrzymał ${ }^{30}$. Przyjęta została także nowa ustawa o niewypłacalności, dająca możliwość nie tylko likwidacji przedsiębiorstw, ale także ich restrukturyzacji.

W Ugandzie wprowadzone zostały reformy mające na celu ograniczenie korupcji i usprawnienie działań służb celnych. W rezultacie w 2008 r. wpływy budżetu wzrosły o $24 \%$ w porównaniu z rokiem 2007.

Rząd etiopski bardzo ambitnie podszedł do usprawnienia systemu sądów handlowych. Wprowadzony został nowy system komputerowy systematyzujący sprawy sądowe, z którym połączyć się można przez internet lub telefon. W czasie przerwy letniej sędziowie - ochotniczo - zajmują się sprawami zaległymi. Wprowadzony niedawno system rejestrujący przedsiębiorstwa automatycznie przesyła informacje do urzędu licencyjnego, oszczędzając czas inwestorów.

Istotne reformy sektora prywatnego podjęly więc przede wszystkim państwa o średnim i niskim dochodzie per capita, niewyróżniające się bogatymi złożami surowców mineralnych. Przywódcy tych państw wydają się zdawać sobie sprawę

30 Ibidem, s. 56. 
z tego, iż jedynie reformy i współpraca międzynarodowa są gwarantami lepszego rozwoju w przyszłości. Z kolei kraje dysponujące atrakcyjnymi złożami mineralnymi odkładają w czasie decyzje o koniecznych zmianach strukturalnych, zadowalając się chwilową dobrą sytuacją ekonomiczną.

\section{Podsumowanie}

Na przestrzeni ostatnich 50 lat (1960-2009) większość państw afrykańskich nie utrzymywała stałego tempa wzrostu gospodarczego, a okresy wzrostu występowały na przemian $\mathrm{z}$ okresami recesji. Porównując tempo wzrostu poszczególnych krajów, zauważamy, że państwa największe (pod względem liczby ludności) rozwijały się wolniej niż pozostałe. Przykładami mogą być Sudan, Demokratyczna Republika Konga, Nigeria i Etiopia. Przed szczególnym wyzwaniem stoją kraje dotknięte w ostatniej dekadzie przez konflikty zbrojne, jak Sudan, Ruanda i Wybrzeże Kości Słoniowej, mające znacznie większe problemy gospodarcze i polityczne niż pozostałe państwa regionu. W latach 90. część krajów Afryki zaczęła rozwijać się szybciej od innych, co było konsekwencją właściwych decyzji gospodarczych: dywersyfikacji produkcji i eksportu, poszukiwania nowych kontrahentów i poprawy klimatu inwestycyjnego. Nie ulega wątpliwości, że wszystkie państwa afrykańskie powinny podjąć próbę dywersyfikacji produkcji w celu uniezależnienia się od cen surowców mineralnych i, w konsekwencji, uwolnienia od stale obecnego ryzyka destabilizacji finansów państwa.

Spadek tempa wzrostu gospodarczego, zaobserwowany w niektórych krajach Afryki, jest konsekwencją m.in. obniżenia napływu inwestycji zagranicznych i spadku tempa wzrostu produkcyjności. Państwa powinny uatrakcyjnić swoją ofertę inwestycyjną, aby przyciągnąć nowych inwestorów, jak również poprawić stopień wykorzystania dostępnych środków finansowych. Większa waga powinna być przykładana do podnoszenia kwalifikacji personelu.

Napływ inwestycji zagranicznych do regionu nie powinien ulec zmniejszeniu, prawdopodobny jest raczej wzrost wolumenu inwestycji, zważywszy na dobre wyniki finansowe państw azjatyckich, będących tradycyjnym źródłem FDI państw Afryki, jak również postępujący wzrost cen surowców. Szczególnie dobrą pozycję wśród państw Afryki Subsaharyjskiej ma RPA, która - jako jedyne państwo afrykańskie 
- zajęła 19 miejsce w rankingu UNCTAD najbardziej pożądanych lokalizacji inwestycji zagranicznych na lata 2010-2012 $2^{31}$. Ze względu na poprawiające się warunki inwestycyjne $\mathrm{w}$ takich krajach jak RPA prawdopodobnie wzrośnie również liczba inwestycji regionalnych.

Stopniowa demokratyzacja kontynentu sprawiła, że decyzje polityczne nie wywierają już determinującego wpływu na wzrost gospodarczy, a ostatnie lata przyniosły znaczną poprawę funkcjonowania instytucji państwowych i politycznych w wielu krajach Afryki. Państwa podjęły szereg reform, które umożliwiły stabilizację ekonomiczną, stopniową liberalizację rynków wewnętrznych i wzmocnienie sektora prywatnego. Aby zapewnić dalszy wzrost regionu, państwa powinny podjąć wysiłek reformatorski na szeroką skalę, ograniczając ingerencję rządów do dziedzin rzeczywiście jej wymagających.

\section{The differences in the economic growth in certain countries of the Sub-Saharan African region}

The purpose of the article is to analyse the economic growth of Sub-Saharan African countriesin the last decades, with special focus on the period 2000-2009.

Economic development in Africa has been mostly positive in recent years with growth pace binge moderate and steady. However, significant differences exist between specific countries, stemming from abundance of mineral resources, location, size of the population or policy of central government. Countries which managed to introduce deep structural reforms, improve the investment climate, diversify output and exports as well as actively searched for new trading partners outperformed. Countries economy which is purely based on exports of crude oil reported also good economic performance,. However influx of investments there as well as general economic development is constrained by risk of the fiscal destabilization, which sudden plunge in commodity prices could originate.

In our research we focused on the following growth indicators: GDP, savings rate, FDI, foreign trade and external aid.

31 World Investment Prospect Survey, 2010-2012, Top Priority Host Economies for FDI for the 2010-2012 period, United Nations, New York and Geneva 2010, s. 13. 


\section{La comparaison de la croissance économique des pays de l'Afrique subsaharienne}

L'objectif de cet article est d'analyser la croissance économique des pays de l'Afrique subsaharienne dans les dernières décennies, tout en mettant un accent particulier sur la période 2000-2009.

La situation macroéconomique de cette région est plutôt positive avec le rythme de croissance modéré et constant. La comparaison des taux de croissance en Afrique subsaharienne conduit à la conclusion qu'il y a des différences considérables entre les pays de la région, résultant de l'abondance des ressources minérales, de l'emplacement, de la population et de la politique du gouvernement. Une accélération de la croissance économique a été enregistrée dans ces pays africains qui avaient décidé d'entreprendre de profondes réformes structurelles, d'améliorer le climat des affaires, de diversifier la production et les exportations ainsi que de chercher activement de nouveaux partenaires. Une bonne performance économique caractérise aussi ces pays dont l'économie est basée uniquement sur les exportations de pétrole, mais les fluctuations des prix des ressources minérales entraînent un risque pérmanent de déstabilisation financière, ce qui limite l'afflux d'investissements et le développement économique. Dans l'article, les facteurs de croissance suivants sont analysés: le PIB, le taux d'épargne, les IDE, le commerce extérieur et l'aide extérieure. 